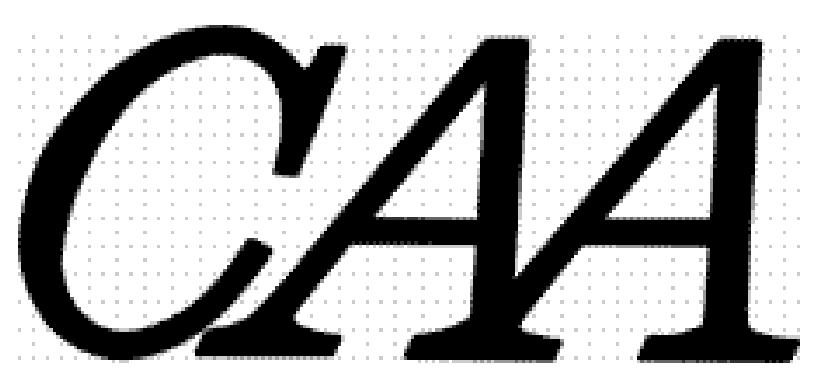

Aeneas or Numa? Rethinking the Meaning of the Ara Pacis Augustae

Author(s): Paul Rehak

Source: The Art Bulletin, Vol. 83, No. 2 (Jun., 2001), pp. 190-208

Published by: College Art Association

Stable URL: http://www.jstor.org/stable/3177206

Accessed: 29/01/2011 11:35

Your use of the JSTOR archive indicates your acceptance of JSTOR's Terms and Conditions of Use, available at http://www.jstor.org/page/info/about/policies/terms.jsp. JSTOR's Terms and Conditions of Use provides, in part, that unless you have obtained prior permission, you may not download an entire issue of a journal or multiple copies of articles, and you may use content in the JSTOR archive only for your personal, non-commercial use.

Please contact the publisher regarding any further use of this work. Publisher contact information may be obtained at http://www.jstor.org/action/showPublisher?publisherCode=caa.

Each copy of any part of a JSTOR transmission must contain the same copyright notice that appears on the screen or printed page of such transmission.

JSTOR is a not-for-profit service that helps scholars, researchers, and students discover, use, and build upon a wide range of content in a trusted digital archive. We use information technology and tools to increase productivity and facilitate new forms of scholarship. For more information about JSTOR, please contact support@jstor.org.

College Art Association is collaborating with JSTOR to digitize, preserve and extend access to The Art Bulletin. 


\section{Aeneas or Numa? Rethinking the Meaning of the Ara Pacis Augustae}

\section{Paul Rehak}

For the modern world, the Ara Pacis Augustae (Altar of Augustan Peace) has come to symbolize the artistic, political, and social achievements of the early Roman Empire, just as the Parthenon at Athens has for Classical Greece. ${ }^{1}$ Constructed between 13 and 9 B.C.E. in the northern Campus Martius in Rome, the altar was closely associated with a giant sundial, the Horologium-Solarium (Fig. 1). Architecturally, the Ara Pacis conflates two types of structure: a Greek form of altar raised on a high podium, and an enclosing rectangular screen wall that resembles a Roman janus with doorways in its east and west facades. ${ }^{2}$ Beginning in the sixteenth century, the remains of the monument were excavated in several campaigns; since the 1930s the reconstituted structure has been on public display in its own protective shell, now being replaced by a new one, designed by Richard Meier, which should be completed late in $2002 .{ }^{3}$ Because of its relatively complete state of preservation and the high quality of its extensive sculptural decoration, the Ara Pacis has overshadowed other monuments, like the Forum of Augustus, that perhaps have an equal or better claim to represent Augustus's principate. ${ }^{4}$ Nevertheless, we use the Ara Pacis confidently as one of the primary structures for viewing Augustan Rome, even though our understanding of the monument is far from secure.

In 1907, Johannes Sieveking proposed that the southern panel relief on the west end of the screen surrounding the Ara Pacis represented the sacrifice of a brood sow by the Trojan hero and Roman ancestor Aeneas, following his arrival in Latium (Fig. 2). ${ }^{5}$ Three ancient authors, Virgil, Dionysios of Halikarnassos, and Varro, provide versions of this story that seem to correspond with details presented on the relief. For nearly a century, archaeologists and historians of ancient art have accepted this identification almost without question and have used the scene as a keystone in attempts to discover the meaning of the monument. ${ }^{6}$ The composition, carved over two joining blocks, focuses on a rustic garlanded altar in front of a tree. At the right are two adult men, both holding staffs; ${ }^{7}$ at the left are two younger individuals, one of whom leads a sow toward the altar. In the background at upper left we can see a small temple whose open end frames two seated male divinities within. The adult nearest the altar is usually identified as the sacrificant, Aeneas, preparing to offer the animal to the Penates, accompanied by the second adult figure, either his son Iulus/Ascanius or his companion Achates.

The purpose of this article is to question the traditional identification of the scene. I will then propose a new and different interpretation of the way this one relief relates to the sculptural program of the Ara Pacis as a whole, to Augustus's use of art and history, and to modern art historical theory and methodology.

\section{The Composition and Iconography of the Panel}

In general, the composition on the Ara Pacis relief conforms to an established Roman type, derived from Hellenistic representations, with a central altar flanked by one or more sacrificants along with the animal victim and attendants, who enter from one side. ${ }^{8}$ The altar may be cylindrical or cubical or stand on tripod legs; the officiating individuals usually have their heads veiled (capite velato) and hold a shallow offering bowl (patera) for pouring libations; at least one assistant leads or urges on the animal victim while others carry trays of offerings or hold ritual equipment. The presence and number of spectators vary. Architectural elements, vegetation, or other landscape features are sometimes added in the background to suggest generic settings or specific locations. So standard is this iconography that it can be considered an artistic topos, whose specific meaning depends on the identity of the "cast of characters" and other details. ${ }^{9}$

Since much recent discussion of the Ara Pacis panel has proceeded from the premise that its subject has already been determined, it seems worthwhile to begin instead with a closer examination of the relief itself before moving on to wider interpretations (Fig. 3). The visual focus of the relief is the central rustic altar in the foreground, carved to represent rough, unworked stones that have been piled up and draped with a garland of laurel leaves. The trunk of an oak tree with foliage rises behind the altar, dividing the scene into two unequal parts. Within each part, the compositional elements differ: the two foreground figures to the right of the altar are nearly as tall as the relief is high, they do not overlap one another, and together they occupy more than half the width of the panel. To the left of the altar the elements are compressed and set in at least three overlapping planes of relief: in the foreground a sow, in the middle distance the two attendants, and in the background a low hill surmounted by a temple.

Of the four human figures on the relief, the sacrificant to the right of the altar is the most prominent because of his position near the center and the frontal pose of his body. $\mathrm{He}$ is a mature, barefoot, and bearded man in archaic costume, the toga sine tunica, which leaves most of his chest and right shoulder and arm bare. Pliny tells us that the statues of the early kings of Rome erected on the Capitoline were similarly garbed. ${ }^{10}$ The sacrificant wears the toga capite velato over a laurel wreath, traits shared on the other remains of the monument only by Augustus in the south frieze. Although he possesses a muscular, classicizing body, his torso has begun to thicken, indicating that he is middle-aged. ${ }^{11}$ His deep-set eye and pronounced naso-labial fold agree with this assessment.

Stylistically, the loose, shaggy locks of the sacrificant's hair, including the beard, and slightly parted lips are features that seem characteristic of Hellenistic sculpture; like much Augustan art, this figure draws from several sources. Similar 
1 Ara Pacis and HorologiumSolarium, northern Campus Martius, Rome, reconstruction drawing (author, after Edmund Buchner)

features characterize the relief head of Aion (Eternity) on the slightly earlier Zoilos Monument from Aphrodisias in Asia Minor (Fig. 4). ${ }^{12}$ Since representations of middle age are uncommon on the Ara Pacis, where youthful and idealized faces are the rule, the maturity of our figure seems a distinct characteristic of his identity. ${ }^{13}$

In the crook of his left arm he cradles a long staff, probably a scepter, since a spear would be inappropriate for a togatus (figure draped in a toga) at a sacrifice, ${ }^{14}$ and he extends his right hand (now missing) over the altar. Originally, he may have been pouring a libation from a patera, as is common in similar sacrifice scenes belonging to this iconographic topos. A number of other paterae appear elsewhere in the decoration of the Ara Pacis. ${ }^{15}$

Although Virgil's Aeneas was once instructed to veil his head for a sacrifice, ${ }^{16}$ the rest of the sacrificant's representation on the relief is inconsistent with the usual iconography of Aeneas in the late Republic and early Imperial period as young, armored, and often beardless. ${ }^{17}$ The characteristic depiction of Aeneas shows the pious warrior who carries his aged father and leads his young son out of Troy on the night it fell. ${ }^{18}$ This iconography, already well established throughout central Italy by the fourth century B.C.E. in a variety of media, continued well into the Roman Imperial period. He was represented in this guise, for example, in one of the sculptural assemblages in the hemicycles of the Forum of Augustus; this statue has not survived, but a wall painting from Pompeii and several sculptural copies or adaptations allow us to imagine how it may have looked. ${ }^{19}$ A similar sculptural group served as an acroterium atop the major temple of Augustus's cult in Rome, the templum novum divi Augusti, begun by Tiberius after his predecessor's death in 14 C.E. and dedicated by Caligula in 37 C.E., at which time the building was also depicted on coins. ${ }^{20}$

To explain the differences between the standard iconography of Aeneas and the individual on the Ara Pacis relief,

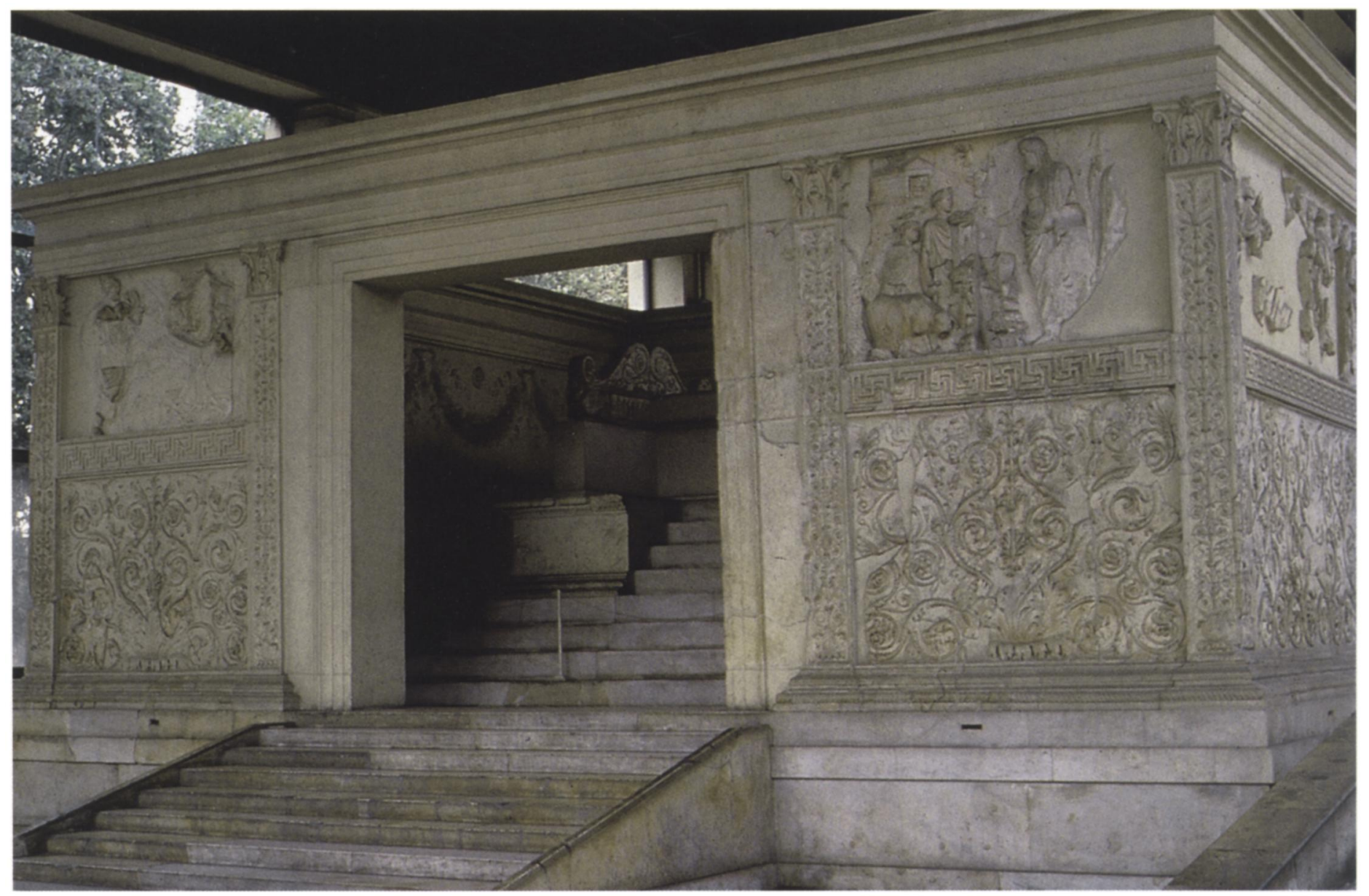

2 Ara Pacis, view of west end (photo: John G. Younger) 


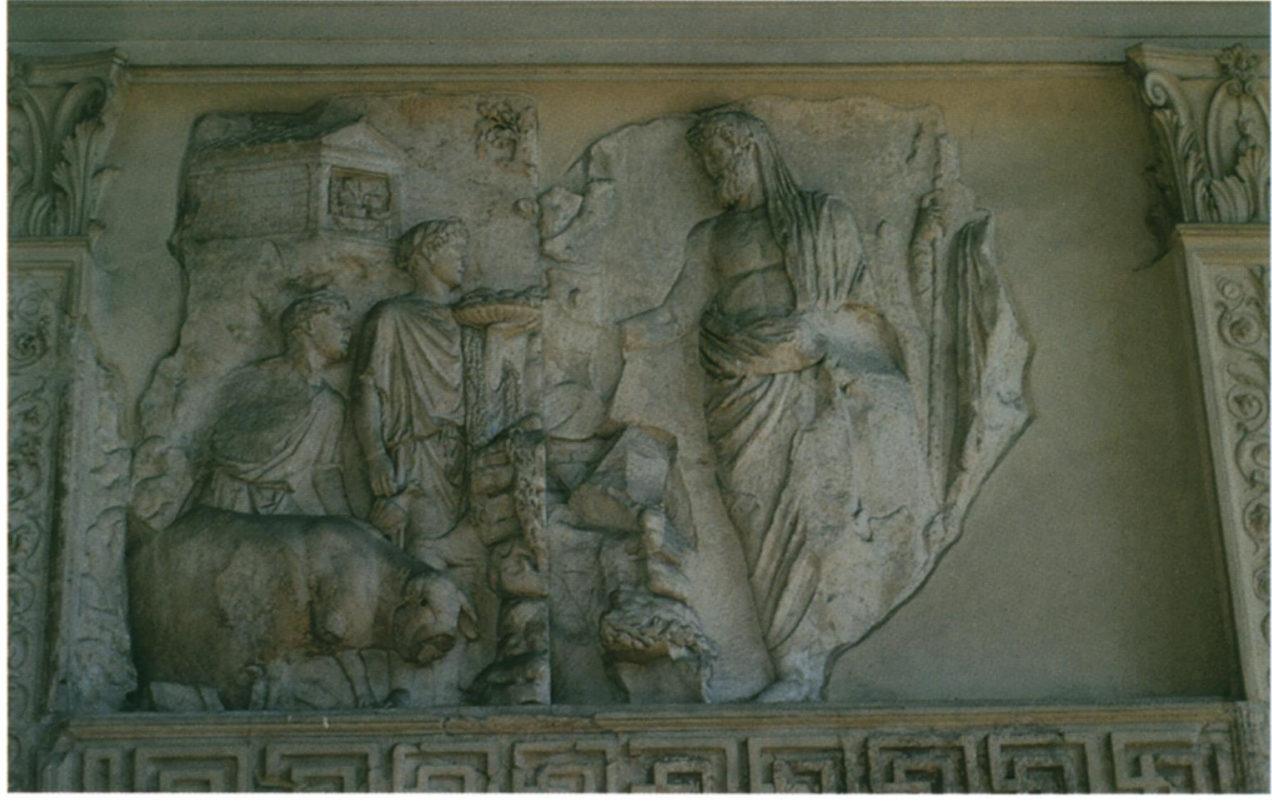

3 Ara Pacis, "Aeneas" panel (photo: John G. Younger)

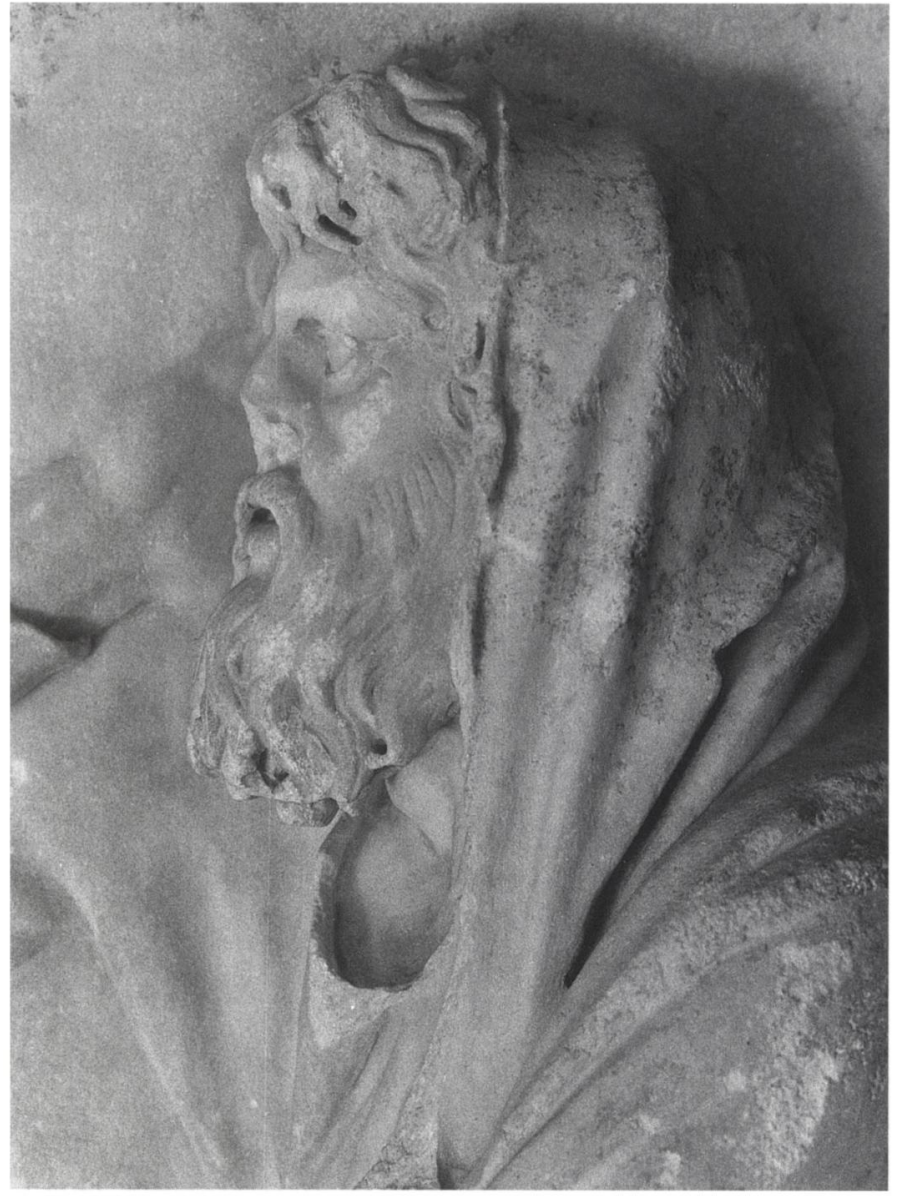

4 Zoilos Monument, head of Aion, Aphrodisias (photo: New York University Excavations at Aphrodisias)

Stefan Weinstock suggested that the Ara Pacis depicts not the hero's sacrifice on his arrival in Italy but a later one, when Aeneas is a venerable king and his son Iulus/Ascanius is grown. ${ }^{21}$ This interpretation, however, ignores the traditional connection of the sacrifice with his arrival (adventus) in Italy and with a foundation myth. ${ }^{22}$ Erika Simon and Paul Zanker have argued instead that the rendering of our figure is an attempt to show pater Aeneas as precursor of Augustus, as the Trojan hero is described in the Aeneid. ${ }^{23}$ Virgil's epic poem was nearly finished when he died in 19 B.C.E., but Augustus did not actually assume the honorific title of pater patriae until 2 B.C.E., the year in which the Forum of Augustus was dedicated $^{24}$-seven years after the Ara Pacis was completed. Although iconographic experimentation is a hallmark of Augustan art generally, the princeps's own mention of the title pater patriae as the last honor in his autobiographical Res gestae makes it clear that he regarded it as the culminating award of his principate, not one he would have assumed earlier. It seems unlikely that such a "paternal" image of Aeneas as stand-in for Augustus would have been anticipated on a state relief a decade earlier.

At the far right of the scene stands another individual carved in high relief, usually identified as Achates, the companion of Aeneas, or as Iulus/Ascanius, Aeneas's son. ${ }^{25}$ Achates is seldom represented artistically, but Iulus/ Ascanius consistently appears in art as a small child in Phrygian costume and cap, holding a short shepherd's staff (pedum) with a curved end. ${ }^{26}$ The relief figure on the Ara Pacis, only partially preserved, wears a long-sleeved tunic with a mantle fastened on the preserved right shoulder; the sensitively rendered fingers of the right hand support another long staff with a slightly knotty surface where small branches have been trimmed away. ${ }^{27}$ The long sleeve indicates that he is not a Roman, and the position of his shoulder-almost level with that of the sacrificant-shows that he must be an adult. Moreover, the staff is too long to be the pedum of Iulus/Ascanius; instead, it complements the long staff or scepter that the sacrificant holds. The two figures are adults, therefore, and equals rather than father and son.

On the left side of the panel, two barefoot attendants approach the altar, clad in short tunics and wearing laurel 
wreaths. The figure on the far left bends forward slightly and urges on a sow, the sacrificial victim. ${ }^{28}$ Closer to the center, slightly overlapped by the altar, stands a second attendant with a fringed napkin, or mantele, draped over the left shoulder. His left hand supports a fluted tray ( $\operatorname{lan} x$ ) with offerings of fruit and cakes near shoulder level, and his right hand holds a pitcher (guttus) carved with crisp flutes that suggest metalware. All three ritual appurtenances have parallels elsewhere on the Ara Pacis, ${ }^{29}$ thus indicating that this ceremony is specifically Roman.

Because of their costume and attributes, the two attendants have been identified respectively as a victimarius (male sacrificial attendant who leads the animal victim) and a camillus (youthful male assistant at a sacrifice who holds the ritual equipment). ${ }^{30}$ The sculptors have indicated that the two youths are not identical: the individual on the left has a noticeably square, blocky head on a thick neck with a pronounced Adam's apple and wears a tunic unfastened in the exomis fashion, leaving the right shoulder bare and exposing part of the chest, now mostly sheared away. The attendant on the right has a more rectangular head with a higher forehead and delicate features, lacks an Adam's apple, and wears a short-sleeved tunic that covers the entire chest area. Over the top of the head, long locks of hair are plaited together in a braid that falls in a loop behind the occiput, with its end secured to the rest of the braid by a small band or fillet. If untied, the long tress of hair at the back would fall well below the shoulders. This braid, seen sometimes in Hellenistic sculpture, is also characteristic of Roman camilli. ${ }^{31}$ Such locks presumably would be cut late in adolescence as a rite of passage. $^{32}$

The camillus in the relief has sometimes been identified as Aeneas's son, Iulus/Ascanius, assisting his father. ${ }^{33}$ But Roman religious law of Augustus's time required that a camillus have two parents living, which would exclude Ascanius, whose mother died in the sack of Troy. Such rules were often projected anachronistically into the mythological past. Because the garlanded and veiled figures of the sacrificing male on the panel and Augustus in the south frieze share certain similarities, it has also been suggested that the camillus also could allude to Gaius Caesar, Augustus's adopted son and presumed heir, who was born in 20 B.C.E. The heights and facial features of both youths in the sacrifice scene, however, suggest that they are adolescent; therefore, it is unlikely that either serves as a reference to Gaius, who was only seven when the altar was founded and eleven when it was completed. ${ }^{34}$

In the foreground, the sow moves toward the altar from the left, as is standard in sacrificial scenes. ${ }^{35}$ Despite damage to the surface of the relief at this point, the outline of her teats shows clearly against the background, ${ }^{36}$ and surviving traces of the trotters show that the animal is on her feet, being urged forward, as in depictions of sacrifice like the suovetaurilia (triple sacrifice of a boar, ram, and bull) on the late Republican Domitius Ahenobarbus Monument (perhaps a statue base) ${ }^{37}$ and the Julio-Claudian suovetaurilia relief in the Musée du Louvre, Paris. ${ }^{38}$ Like all creatures on the Ara Pacis, the animal is relatively small in relation to the people, but as she lacks her thirty piglets, this cannot be the immense sow (even if scaled down) that was prophesied to Aeneas. Several early Imperial reliefs, including the Belvedere Altar in the

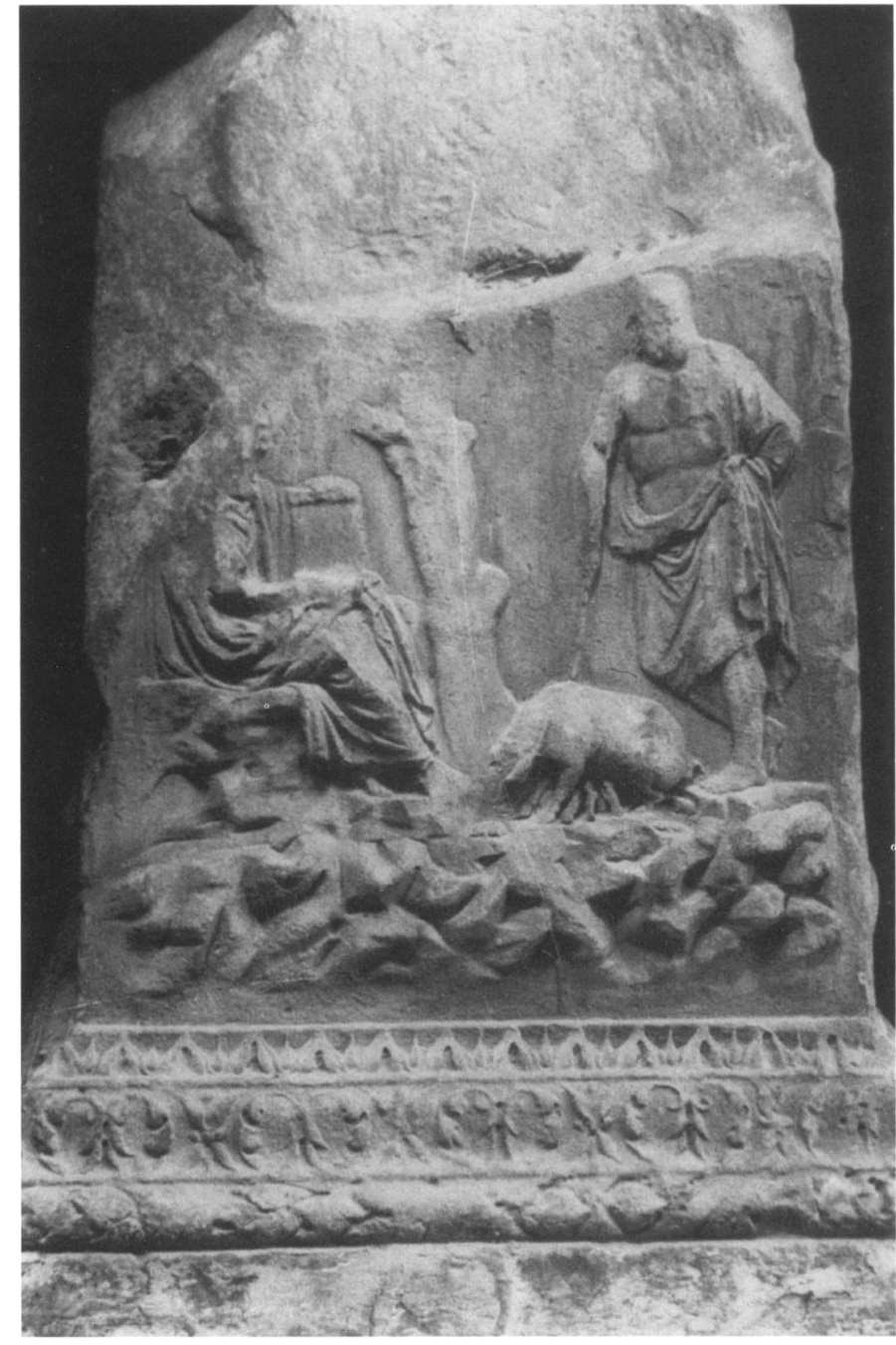

5 Belvedere Altar. Museo Gregoriano Profano, the Vatican (photo: courtesy Deutsches Archäologisches Institut, Rome)

Vatican (Fig. 5), include litters of piglets and demonstrate that sculptors were capable of depicting them. ${ }^{39}$ Moreover, we should distinguish between the sacrifice scene in literature, where the recumbent sow and her piglets are the focus, and this sacrificial scene, in which an animal is accessory, advancing toward a central altar that is the main focus.

We know of relatively few sacrifices of single pigs or sows that would be appropriate for depiction on a state monument; ${ }^{40}$ the suovetaurilia sacrifice combines the offering of a boar, a ram, and a bull. During the celebration of the Secular Games in 17 B.C.E., Augustus sacrificed a pregnant sow to the earth goddess, Terra Mater, as part of his ceremonial inauguration of a new cycle (saeculum) in Rome's existence, ${ }^{41}$ and a coin of 16 B.C.E. depicts two men wearing togas capite velato holding a small sow over an altar, as a reference to the archaic peace treaty between Rome and the town of Gabii during the time of the Etruscan kings (Fig. 6).$^{42}$ We will come back to this last occasion.

In the background on the Ara Pacis relief above the animal victim and attendants is a small temple on a hill, containing 


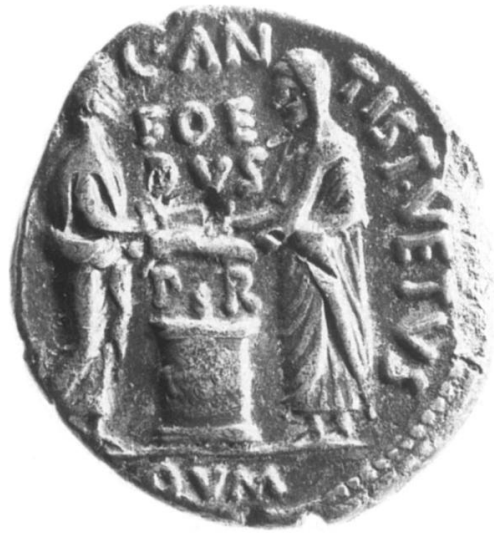

6 Coin of 16 B.C.E. with sacrifice of sow. London, the British Museum (photo: courtesy the British Museum)

the seated divinities that we assume are to be recipients of the sacrifice (Fig. 7). Two sides of the shrine are visible, rendered in perspective as if the building were set in the distance. ${ }^{43}$ Considerable attention was devoted to its architectural details: one long side wall of ashlar blocks, three visible corner pilasters with Corinthian capitals (like those that actually frame the corners and doorways of the Ara Pacis enclosure), the tiled roof, front pediment (decorated with a patera and a pair of litui, the short staffs with curved ends held by augural priests), and floral acroteria. ${ }^{44}$ The highly detailed and sophisticated architecture of the building stands in marked contrast to the rustic altar in the foreground of the panel. Nevertheless, there is a garland draped across the open facade of the shrine in the same manner as the garland draped across the altar, creating a thematic and visual link between the two constructions.

The opening at one end of the shrine is closed not by the paneled doors characteristic of temples but by a pair of low gates carved to represent wickerwork and surmounted by a row of inverted dentils. ${ }^{45}$ Behind these gates we can see two seated figures holding long staffs. Despite their small scale it is clear that the figures have drapery around their thighs but

bare, muscular chests; the preserved head of the figure on the left turns slightly toward the center, as if the pair are conversing. Although the head is worn, a detail (Fig. 8) shows that the lower part of the face extends down to the trachea at the base of the neck; this roughened area, too massive to be simply a prognathous jaw, must instead represent a full beard. These traits indicate conclusively that these individuals cannot represent the divinities mentioned in our three main literary sources. According to Virgil, Aeneas's sacrifice is to the goddess Juno; in Varro it is to the household gods; and in Dionysios it is to the Penates, in a shrine erected after the sacrifice took place. In any case, the Penates typically are represented as two youths, like the Dioscuri, in military garb, holding spears. ${ }^{46}$ These mature seated figures with bare upper bodies more likely represent major male deities such as Jupiter and Dis/Pluto, who are often depicted in this manner. Even though the details described here may have been too small for most Augustan viewers to appreciate from ground level in front of the Ara Pacis, it is obvious from the careful work that the sculptors knew what they intended to represent, and in antiquity the addition of paint might have enhanced the contrast between exposed flesh and drapery.

Scholars have usually argued that the occupants of the temple are observing the sacrifice at the altar, a simile for the gods observing sacrifices at the inner altar of the Ara Pacis. Recently, Jás Elsner has devoted two long discussions to this issue, and he has stated that the sacrifice on the panel is the same as the one that actually took place on the inner altar of the Ara Pacis. ${ }^{47}$ This is certainly incorrect, for Augustus specifies in the Res gestae that the magistrates, priests, and Vestals were to participate in an annual sacrifice (anniversarium sacrificium) at the Ara Pacis, ${ }^{48}$ and the frieze of the inner altar, even in its present fragmentary state, depicts the Vestals and some male figures along with two bovids and a sheep; no pig is preserved. ${ }^{49}$

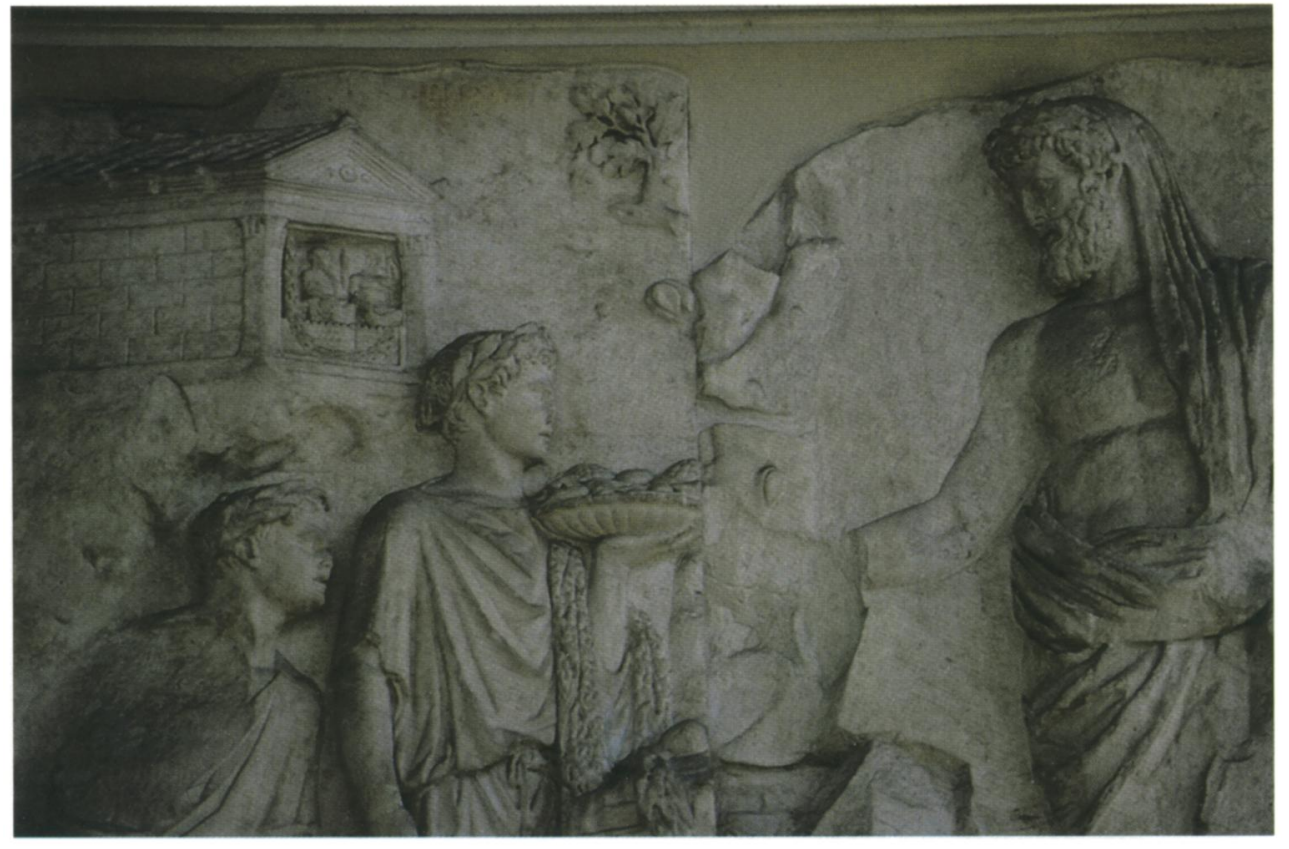

7 "Aeneas" panel, detail (photo: John G. Younger) 
8 "Aeneas" panel, detail of seated figures (courtesy L. Richardson Jr.; photo: Johannes Felbermeyer)

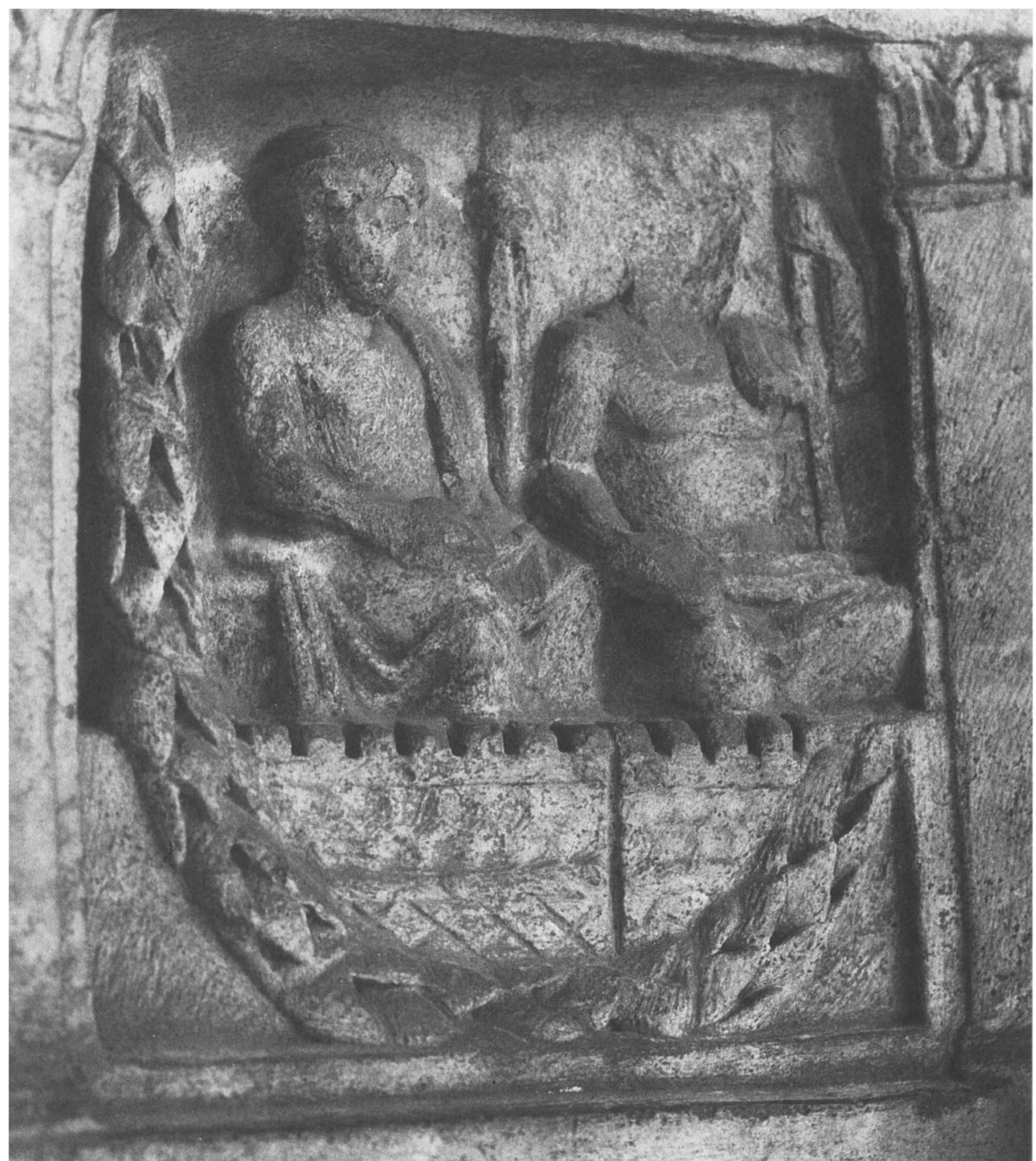

\section{The Textual Evidence}

Although several literary sources for the sacrifice of Aeneas belong to the Augustan period, the story was well known at least from the late Republic. ${ }^{50}$ It is worth examining these texts in detail.

Virgil refers to the sacrifice of the sow three times in the Aeneid. As noted earlier, this epic was nearly complete at the time of the poet's death in 19 B.C.E.; thus, his version of the story was presumably well known when the Ara Pacis was conceived and constructed between 13 and 9 B.C.E. Before reaching Italy, the Trojans landed in Illyria, where a colony of fellow refugees had already settled. There, the seer Helenus warns Aeneas that in the future he will discover an animal that is to be a portent for the foundation of the town of Lavinium (Aeneid 3.388-93): $:^{51}$

I will give you signs: keep them firmly in mind. When you are in distress, by the water of a secluded stream, you will find a huge sow recumbent on the shore under the oaks, just delivered of thirty piglets. She is white and white the newborn piglets-there will be your city, and a secure rest from your labors.
On their subsequent arrival in the peninsula, Aeneas sends peaceful envoys to all the Latins, but Juno stirs up hostilities that ultimately lead to war. Tiberinus, the god of the river Tiber, appears in a dream to the restless and troubled Aeneas and repeats verbatim Helenus's earlier omen concerning the sow and her brood (Aen. 8.36-48). The next day the hero finally discovers the animal with her litter and offers all of them to Juno (Aen. 8.81-85): ${ }^{52}$ "But behold the marvelous portent that suddenly appears before your eyes, shining white through the woods with her brood the same white color, stretched out on the green bank. Pious Aeneas offers them to you, great Juno, placing her and the young on your altar."

The narrative of Dionysios of Halikarnassos is somewhat different, perhaps following an annalistic tradition and not Virgil's source. ${ }^{53}$ In this account, Aeneas is ordered by a sibyl on Mt. Ida to sail west; on landing in Italy he is to follow an animal until it wearies and there found a city. ${ }^{54}$ Aeneas and his forces land at Laurentum on the Italian coast and offer a sacrifice to Helios (Sol) for the fresh water they find there. After a meal, Aeneas sets up the images of the Trojan gods and prepares to sacrifice a gravid white sow to them. She 
escapes, however, and flees inland; Aeneas, recognizing the omen, follows her for twenty-four stades with a few of his men. Eventually she lies down and the next day gives birth to thirty piglets. Aeneas then sacrifices them all (Dion. Hal. 1.57.1): ${ }^{55}$ "And Aeneas sacrificed the sow, together with her brood, to his paternal gods in the very spot where a shrine now stands. The Lavinians consider this shrine sacred, and prevent all from entering it except themselves."

Finally comes Varro's account (De lingua latina 5.144$):^{56}$

Lavinium is the first fortified settlement of the Roman race which was founded in Latium: for there are our Penates. This town was named after Lavinia, the daughter of Latinus, who married Aeneas. From here another fortified settlement was founded thirty years later: it takes its name from the white $[a l b a]$ sow. She had escaped to the site of Lavinium from Aeneas's ship and there bore her piglets; from this portent a second city was created thirty years after Lavinium and called Alba Longa, because of the sow's color and the [elongated] shape of the site.

Clearly, the literary accounts do not match what we see on the Ara Pacis relief. All three versions include the sow with thirty piglets, and the latter are important because they foreshadow the founding of Alba Longa after Lavinium. ${ }^{57}$ It can hardly be argued that the piglets have been omitted for lack of space on our panel, ${ }^{58}$ since other smaller early Imperial reliefs include at least some of them, like one face of the Belvedere Altar, mentioned above, which may illustrate Helenus's prophecy to Aeneas (Fig. 5) ${ }^{59}$

Furthermore, Aeneas's sacrifice has no clear association with peace, and no direct connection even with Rome. In the literary versions of the story, the landing of Aeneas was connected with the foundation of Lavinium, where the portent of the sow and her young foretells the creation of Alba Longa thirty years afterward. Rhea Silvia, the mother of Romulus and Remus, came from Alba many generations after its establishment, but her relation to Aeneas's sacrifice is remote at best. Finally, Aeneas's arrival signaled the beginning of long battles between the newcomers and the native populations of Italy. His advent brought war, not peace. So strong is Aeneas's connection with war, in fact, that Weinstock once used the traditional identification of our relief to suggest that the monument to which it belongs could not be the Ara Pacis. ${ }^{60}$

\section{A New Interpretation}

The iconography of the sacrificant is not consistent with that of the early Imperial Aeneas. His non-Roman adult associate is represented as an equal, not a subordinate or even a youth, let alone a child. The sow lacks her thirty piglets. The deities observing the sacrifice are not the gods mentioned in the literary accounts of Aeneas's sacrifice. The sacrificial attendants, a victimarius and a camillus, indicate that this is a typically Roman sacrifice, but neither individual makes a convincing Iulus/Ascanius. And, finally, Aeneas's sacrifice has nothing to do with peace and everything to do with the founding of cities other than Rome. Thus, on the grounds of both iconography and text, an identification of the scene as the sacrifice of Aeneas seems untenable.
What else could this panel relief represent? Here I think we need to consider the details the panel actually presents: two sceptered kings, one an archaic Roman by costume and the other non-Roman, offering a sow in the presence of a pair of mature male divinities, assisted by a victimarius and a camillus, and thus a Roman ritual. All the human figures are barefoot, suggesting a simpler, less sophisticated era than the Augustan age. A scene involving Numa Pompilius, the second king of Rome, fits all of these requirements. ${ }^{61}$

According to tradition, Numa (r. $715-673$ B.C.E.) was the great civil and sacred lawgiver of regnal Rome. His prominent role as the founder of the original temple of Janus to serve as an "indicator of war and peace" (index belli pacisque) immediately suggests an obvious link with the janiform shape of the Ara Pacis enclosure. ${ }^{62}$ In addition, two of Numa's important religious acts can be located in the Campus Martius, not far from where the Ara Pacis stood: a sacrifice to Mars to confirm the concordia between the Romans and Sabines, ${ }^{63}$ and his establishment of the Fetial Law, which provided specific rules for waging a just war (bellum iustum) against foreign enemies and for framing terms for the establishment of peace ${ }^{64}$ Dionysios of Halikarnassos even cites a specific occasion: when Numa was about to go to war with the nearby town of Fidenae he averted the hostilities and thus was able to preserve an unblemished record of peace during his reign. ${ }^{65}$

Under the Republic, the Fetiales constituted a priestly college charged with overseeing declarations of war and establishments of peace. Before Rome declared war against an enemy, restitution (rerum repetitio) was demanded in a formal procedure, which allowed the opponent thirty (or thirtythree) days to respond. ${ }^{66}$ If no satisfactory answer was forthcoming, the Fetiales convened and one member acting for the rest threw a spear into or toward the hostile territory, and war was declared. This ceremony, which originally took place at the border, later was located at a freestanding war column, the columna bellica, in the precinct of Bellona outside the pomerium (sacred boundary of the city) in the southern Campus Martius, where a small plot of land had been designated as "foreign territory" in perpetuity. ${ }^{67}$ If reparations were made in time, war was averted, and peace could be established. To seal a treaty of peace, the Romans sacrificed a sow, as is depicted on the coin of 16 B.C.E. mentioned above, which commemorated the archaic treaty between Gabii and Rome (Fig. 6). ${ }^{68}$

Although the Fetial Law was invoked a number of times during the Republic, the practice seems to have fallen into desuetude before Octavian revived (and perhaps reshaped) the tradition in 32 B.C.E. before the Battle of Actium. To establish the justness of his war against Antony, Octavian staged the fetial ceremony in the Campus Martius; since he mentions in the Res gestae that he was a fetial priest, perhaps he himself threw the traditional spear over the columna bellica on behalf of the confraternity. ${ }^{69}$ An important aspect of Octavian's propaganda at the time was the representation of Antony as "foreign" and "non-Roman," even though Cleopatra was the official enemy. ${ }^{70}$ There is, however, no evidence that the college was actually sent to Alexandria to demand rerum repetitio, as tradition demanded; Octavian's ceremony was a symbolic gesture to impress the people of Rome. ${ }^{71}$ 
With the final defeat and deaths of Antony and Cleopatra in 30 B.C.E., Octavian gained control of the Roman world and closed the doors of Janus as a sign that peace had been restored. Since Numa was the original founder of the temple of Janus and because he had set out the rules for establishing peace, his was a model to follow and emulate.

I propose that the Ara Pacis panel shows King Numa, originator of the Fetial Law, sacrificing a sow with a foreign king to guarantee peace. Since the emphasis is on Numa's role as peacekeeper, the other king is relegated to a position behind him, rather than facing him on the opposite side of the altar. To seal the pact an oath is sworn to the celestial and infernal gods as witnesses, a pantheon here represented by just a pair of divinities, Jupiter and Dis, the two mature male figures in the small temple on the relief. The gods are guarantors of the oath, not the recipients of the sacrifice. Most important, the rustic altar that serves as the compositional focus at the center of the scene would be the first Roman "altar of peace"- that is, a forerunner to the Augustan monument. If this interpretation is correct, then the two young sacrificial attendants could even be the children of the two kings, though this interpretation does not depend on it. ${ }^{72}$

This identification of Numa and the sacrifice of peace is congruent with the rest of the sculptural program of the Ara Pacis. At the west end of the monument two panel reliefs flank the central entrance (Fig. 2); the south panel depicts Numa, while the north panel apparently showed the infants Romulus and Remus being discovered by their adoptive father, Faustulus, in the presence of their real father, Mars, the eponymous god of the Campus Martius. ${ }^{73}$ It is clear that the two panels on the west end of the monument are meant to be understood as a pair, not only because of their structural symmetry flanking the doorway but also because of their thematic symmetry: Romulus the warrior was the first king of Rome, and Numa the peacemaker the second. Although the Romans abominated the memory of the later Etruscan kings of Rome, a long tradition approved of both Romulus, who was renowned for the arts of war, and Numa, renowned for the arts of peace. Together they offered a model for effective governance.

Thus, in a sense the west front of the Ara Pacis becomes the visual expression of Virgil's description in book 6 of the Aeneid, where Augustus appears framed between Romulus and Numa as part of the poetic vision of Rome's future empire (imperium) granted to Aeneas when he visits the underworld. First comes the description of Romulus as son of Mars, followed by Augustus himself, with Virgil's famous description of his world rule, and then Numa:

A son of Mars will join his grandfather's line-Romulus, whom his mother bore to the family of Trojan Assaracus. Do you see how double plumes rise upon his helmet, and how his father himself designates him for life on earth? My child, under his auspices renowned Rome will enclose her empire [imperium] on earth and her pride by heaven, and one city wall will enclose the seven hills, fortunate in her family of men. (description of Romulus, 6.777-83)

Now cast your eyes over here; behold this people, your own Romans. Here is [Augustus] Caesar, and all the de- scendants of Iulus who are destined to come beneath the great dome of heaven. Here, here is the man whom you have heard promised so often, Augustus Caesar, the son of a god [Julius Caesar], who will establish the golden age again among the fields where Saturn reigned once, and extend his empire [imperium] beyond the Garamants and Indians, a land that lies beyond the stars, beyond the paths of the year and the sun, where sky-bearing Atlas turns the vault of heaven, burning with stars, upon his shoulders. Even now the kingdoms beyond the Caspian Sea and the Maeotian land shudder in response to these heavenly oracles: the sevenfold mouths of the Nile roil in terror. (description of Augustus, 6.788-800)

But who is he, standing apart, bearing the sacrifice with his head wreathed in olive twigs? I recognize the long locks and gray chin of that Roman king, who built our city on laws, when he was sent from the poor land of insignificant Cures to take control of a great power [imperium magnum]. (description of Numa, 6.808-10) ${ }^{74}$

\section{The Image of Numa}

Because we have accepted a blanket view from Roman authors that monarchy is "bad," almost no attention has been paid to the possible appearance of a king of Rome on the Ara Pacis apart from Romulus, who is shown as a child. Numa has also been neglected as a candidate because his image seems relatively unknown to modern scholarship, ${ }^{75}$ in contrast to Romulus and Aeneas, both of whom have strongly developed iconographies-and, in the case of Aeneas, the authority of the Aeneid to bolster him.

Romulus and Aeneas were also considered ancestors of the gens Julia to which Augustus belonged. Nevertheless, the princeps could claim descent from Numa as well as through Julius Caesar: on his mother's side, Caesar was descended from King Ancus Marcius, the grandson of Numa by his daughter. ${ }^{76}$ In addition, a well-defined tradition about Numa goes back at least to the epic poet Ennius in the third century B.C.E., as well as to an iconographic type represented by the statue of the king on the Capitoline Hill, thought to have been erected during the regal period (before 509 B.C.E.). ${ }^{77}$ As a counterpart to Romulus, Numa features prominently in the writings of Cicero, including his works De republica, De oratore, and De natura deorum, all of which were composed near the middle of the first century B.C.E., well before Augustus's rise to power. ${ }^{78}$ About the time that Octavian assumed the title "Augustus" (January 17, 27 B.C.E.), Livy had recently published the first book of his history of Rome, in which the portrait of Numa as peaceful king and "culture hero" is very clearly defined as a foil to the warlike Romulus. ${ }^{79}$

In addition, Numa acquired an iconography that consistently presents him as a mature bearded man. While we do not know in detail what his statue on the Capitoline Hill looked like, he appears on a number of coins of the first century B.C.E. ${ }^{80}$ A denarius minted by L. Pomponius Molo (ca. 97 B.c.E.?) depicts a laureate head of Apollo on the obverse and on the reverse a sacrificial scene carrying the legend NVMA POMPIL (Fig. 9). ${ }^{81}$ The composition includes a togate Numa holding an augural lituus to the left of a flaming altar while a victimarius introduces a goat from the right. The 


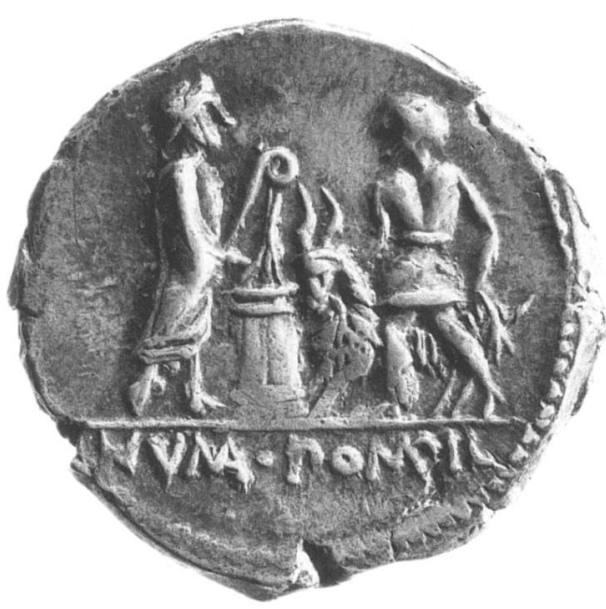

9 Coin of L. Pomponius Molo, ca. 97 B.c.E.? London, the British Museum (photo: courtesy the British Museum)

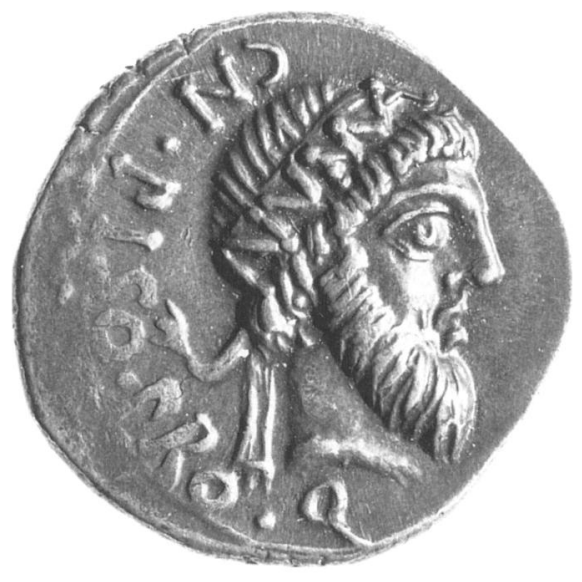

10 Coin of Pompey the Great, 49 в.C.E. London, the British Museum (photo: courtesy the British Museum)

asses and denarii minted by C. Marcius Censorinus (ca. 87 B.C.E.) show him in profile as a bearded and diademed man. ${ }^{82}$ On a coin of Pompey the Great (49 B.C.E.) the bearded head of Numa appears in profile, wearing a diadem inscribed NVMA (Fig. 10).$^{83}$ In the Augustan period, the tresviri monetales (the board of men responsible for minting coins) issued an unusual as in 23 B.C.E. that showed the head of Augustus on one side and the bearded head of Numa on the other, stressing the connection between the two individuals. ${ }^{84}$ These last two coins are important because they were struck under the authority of Cnaeus Calpurnius Piso and his son, respectively; like Augustus, the Calpurnii could claim descent from Numa, and Andrew Wallace-Hadrill has tentatively hypothesized that the introduction of the "new" Augustan coinage was meant to recall Numa's putative creation of the first Roman money. ${ }^{85}$ While it is easy for us to neglect the value of ancient currency as a means of disseminating official images, these minted pieces of metal passed repeatedly through the hands and under the gaze of the public.

\section{Numa and Augustus: Parallel Lives}

Thus, Numa served as a plausible and acceptable model for Augustus to follow. Here we can concentrate on a few of the more important points of contact between the two rulers. Numa was reluctant to rule, and when he was invited by the
Senate and people to become king of Rome, he accepted only when the gods confirmed his right to rule. Appropriately, with his head veiled he had the omens taken on the Capitoline Hill, accompanied by augurs and priests, and received the requested signs. ${ }^{86}$ Octavian also made a show of his reluctance to rule on a number of occasions, ${ }^{87}$ and in 27 B.C.E. when he adopted the title Augustus in January he was careful to emphasize that he was doing so with human and divine approval. ${ }^{88}$ As a number of studies have pointed out, his title is connected with the terms augur and augury, and also with the verb augeo (to increase, enrich, bless). This occasion also illustrates Augustus's antiquarian interests and his careful attempts to legitimize himself by appealing to tradition, for a famous quote by the poet Ennius describes how Romulus had founded Rome by "august augury." ${ }^{89}$ Furthermore, Augustus and Numa, as well as Romulus, came to be considered city founders. ${ }^{90}$

As mentioned earlier, Numa founded the temple of Janus in the Roman Forum, whose doors were closed during peace and open in times of war. ${ }^{91}$ Significantly, Janus remained closed throughout the king's reign. Augustus emphasizes in the Res gestae that the Senate voted to close the temple of Janus three times during his principate, the first time after the Battle of Actium, when he also took the most important Roman augury, the augurium salutis; ${ }^{92}$ this is also the only place in the document where he mentions his own birth, a point that will become meaningful when we turn below to the broader meaning of the Ara Pacis. ${ }^{93}$

Ancient sources also credit Numa with establishing all the major priesthoods of the Roman state religion. ${ }^{94}$ Some of the earliest coins of Octavian label him pontifex and augur; ${ }^{95}$ as princeps, he went on to accumulate more priesthoods than any other Roman up to his day, ${ }^{96}$ culminating in his assumption of the role of pontifex maximus in March of 12 B.C.E., while the Ara Pacis was under construction. ${ }^{97}$ Eventually, Augustus linked himself with many aspects of the state religion; within the grounds of his house on the Palatine Hill he set aside plots of land for the temple of Apollo Palatinus and a shrine of Vesta, and his name was included in the Hymn of the Salii, the dancing priests of Mars. He created a new priest, the flamen Iulialis, to supervise the cult of the deified Julius Caesar, just as Numa had created the flamen Quirinalis for the worship of Romulus as a god after his death. As if to underscore the importance of Augustus's religious and political affiliations, the south frieze of the Ara Pacis places him after the lictores, among men who may represent the pontifices, and at the head of the flamines, not among the members of his family. ${ }^{98}$

Under the direction of the pontifex maximus, the pontifices were also responsible for the maintenance of the calendar, and Augustus played an active role in instituting the calendrical reforms that Julius Caesar had proposed before his assassination. Similarly, Numa was said to have reformed the calendar established by Romulus; he made January the beginning of the year and inserted the intercalary month to create a cycle that repeated itself every twenty years. ${ }^{99}$

Numa created and reformed civic institutions, divided the country into districts, and established overseers and patrols, ${ }^{100}$ foreshadowing Augustus's division of Rome into fourteen districts (regiones), supervised by the vicomagistri who 
maintained city services and attended to the new cult of the Lares and Genius Augusti, created in the years immediately after the construction of the Ara Pacis. ${ }^{101}$ Numa embellished the city with major buildings, including the Regia and the temple of Quirinus; Augustus restored the latter, and after becoming pontifex maximus in 12 B.C.E. he had the right to reside at the Regia, even though he chose not to. ${ }^{102}$ Even the anachronistic Pythagoreanism of Numa has some interesting points of contact with Augustus's circle of intimates, including the poet Virgil. ${ }^{103}$

Following the lengthy wars of Romulus, which increased the territory of Rome, Numa instituted peace and promoted agriculture, the rearing of children, and the proper worship of the gods. ${ }^{104}$ These ideal goals are very similar to the objectives of Augustus's social and moral legislation, which stressed the importance of farming and increasing the size of Roman families. ${ }^{105}$ These are always considered the tangible benefits of peace.

\section{The Ara Pacis as a Representation of Augustan Rule}

With these links between Augustus and Numa in mind, the decorative program of the Ara Pacis can be better understood. As the panels of the west end flank the central doorway and form a pair depicting Romulus and Numa, so the panels on the east end form another pair, with the well-known seated figures conventionally called Tellus (probably Pax herself) on the south side ${ }^{106}$ and Roma on the north side $\mathrm{e}^{107}$ facing one another across the back entrance (Fig. 11). Pax and Roma function as allegories of Peace and War. ${ }^{108}$ Thus, on the southern half of the monument, the peaceful king Numa at the west end corresponds with Pax at the east end, and on the northern half the warlike Romulus at the west end corresponds with Roma on the east end. ${ }^{109}$

The peaceful panels with Numa and Pax thus frame the south processional frieze, which includes Augustus with priests and lictors, followed by members of the imperial family. To strengthen this connection, Numa and Augustus are the only male figures on the altar who are garlanded and veiled, and Livia in the south frieze and Pax on the east end panel are the only women who are garlanded and veiled. ${ }^{110}$

A similar arrangement obtains on the north half of the enclosure wall. The end panels with Romulus and Roma frame the north processional frieze, in which the figures move parallel to those in the south frieze, perhaps representing the same procession as if seen from the opposite side. ${ }^{111}$ The procession of the north frieze is often said to include senators, but very few of the togate individuals wear the distinctive senatorial shoes (calcei senatorii), and at least two camilli are present, carrying acerrae, or boxes for incense. ${ }^{112}$ Thus, the north frieze likely depicts more priests, followed by additional members of the family of Augustus. Richard Billows has argued in detail that the long processions constitute a supplicatio, or solemn religious celebration, offered on July 4, 13 B.C.E., the date of Augustus's return to Rome from the western provinces and the occasion for consecrating the Ara Pacis. ${ }^{113}$

While Augustus embodies aspects of both Romulus and Numa, his location in the south frieze rather than the north makes it quite clear that the balance on the monument tips in the direction of peace. Underscoring this

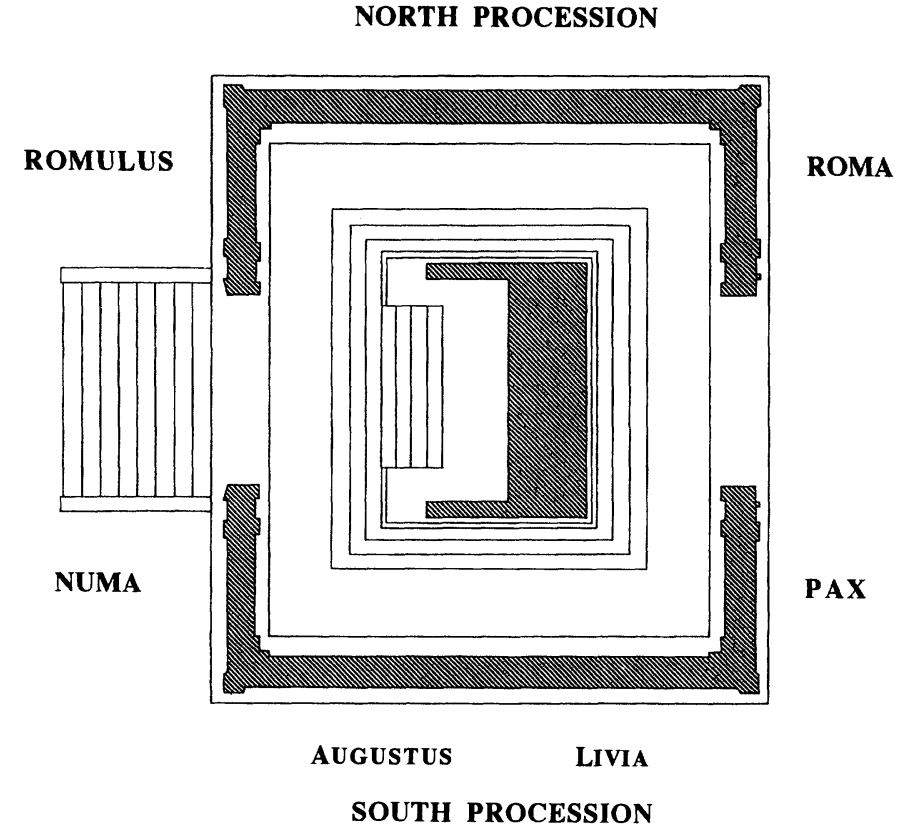

11 Diagram of the Ara Pacis (author, after Simon, Augustus, 1986, 32, fig. 28)

aspect are the togate depictions of Augustus and many other figures on the north and south friezes, including several children; only one individual on the monument appears in military garb, the figure identified as Livia's son Drusus (S-39) in the south frieze. ${ }^{114}$ The extensive floral panels under the figural friezes and end panels on the exterior of the precinct wall reinforce the theme of peace of the monument, ${ }^{115}$ while on the interior the frieze of garlands suspended between the skulls of sacrificed bulls (bucrania) highlights the importance of the proper observance of religion in the new order of Augustus. The fragmentary female figures from the base of the inner altar may represent pacified provinces. ${ }^{116}$

Therefore, this reidentification of the "Aeneas" panel as Numa permits a much simpler, but potentially more nuanced and unified, interpretation of the figural friezes and panels around the exterior wall of the Ara Pacis. If this interpretation is acceptable, then many earlier proposals become untenable. The panel reliefs cannot reflect foundation myths linking the origin of Rome (Romulus) with the origin of the Julian gens (Aeneas), ${ }^{117}$ a reading that is prompted largely by statues of these individuals displayed in the "portrait galleries" of the hemicycles of the Forum of Augustus. The Forum Augusti and the Ara Pacis, however, are different monuments with different purposes; it would be simplistic to expect that all Augustan buildings repeat the same message. ${ }^{118}$ Nor can the Ara Pacis panels illustrate beginnings of Roman institutions, in the sense that Peter Holliday has suggested, with the city represented by the wolf in the Romulus panel and the sacrificial sow standing for the Julian family in the "Aeneas" panel. ${ }^{119}$ And although Mars may be represented as pater in the Romulus relief, there is no corresponding figure of pater Aeneas, if our bearded male represents the paternalistic Numa instead. ${ }^{120}$ Without the presence of Aeneas, the identification of the peaceful goddess on one end panel as his mother Venus, rather than Pax, becomes unlikely; further- 
more, there is no need to connect the Ara Pacis with the theme of Trojan origins or the descent of Augustus from Aeneas. ${ }^{121}$ The pairing of Romulus and Numa, however, would illustrate Rome's original founding kings whose lives served as paradigms for Augustus's own career-a career that included an earlier warlike phase followed by a more peaceful mature phase.

This simpler, more balanced message is appropriate to the intimacy of the Ara Pacis. But art historians and archaeologists have generated complicated and obscure messages for this building demanding exegesis on the highest and most abstruse intellectual level, as if it were a complicated literary text writ in marble and not a monument to be understood with the eye. Surely the opposite is true: in order to communicate with the public, public monuments (especially in a capital city) have to convey their messages as directly as possible so that common people and foreign visitors can understand them. This is especially true of a relatively small and accessible structure like the Ara Pacis, embellished with architectural sculpture set so close to eye level that spectators are encouraged to approach, to walk around it, and to consider and reflect on the princeps and his accomplishments in a way that they could not with a larger building. The message of the Ara Pacis is about the exercise of power and the creation of a valid status quo. It concerns not only the balance of war and peace as personified by Romulus and Numa but also the continuity of that balance as personified by Augustus. Moreover, unlike an imperial forum, which creates a closed environment within its surrounding walls and colonnades, ${ }^{122}$ the physical setting of the Ara Pacis encouraged the viewer to look outward and consider the other Augustan buildings in the northern Campus Martius.

This is not to say that the Ara Pacis had only a single message to convey. Recent scholarly theory has focused on the various ways in which visual narratives in sculpture serve programmatic purposes, and often these images suggest multiple levels of interpretation. ${ }^{123}$ Although the end panels of the Ara Pacis are often compared to Hellenistic reliefs, their form and subject matter also bring to mind the famous mythological panel paintings, executed by noted Greek artists, that decorated many buildings of Augustan Rome. ${ }^{124}$ Virgil describes similar large pictures decorating the temple of Juno in Carthage in book 1 of the Aeneid that move Aeneas to tears when he views them. ${ }^{125}$ The Ara Pacis reliefs play off the traditions of ekphrasis in part by introducing change; its panels, after all, are not paintings but sculpture, they are Roman creations rather than Greek imports, their mythological or allegorical themes are Roman, not Hellenic, and they decorate the exterior walls of an altar precinct honoring Augustus's peace, not the interior of a building. ${ }^{126}$

\section{The Ara Pacis as a Monarchical Statement}

Modern scholarship has also accepted at face value Augustus's public characterization of himself as nonmonarchical. ${ }^{127}$ But surely such a view is naive: the Ara Pacis, with its themes of peace and war, refers to King Numa and Romulus and is part of a larger building program in the northern Campus Martius whose major components emphasize the unique position of Augustus with respect to contemporary Romans and to cosmic time. ${ }^{128}$

The altar was built in a section of the Campus Martius that Augustus had developed privately, probably beginning as early as 30 B.C.E. (Fig. 1). ${ }^{129}$ In the distance, viewers could also see the mausoleum of Augustus, the largest Roman tomb built at that time and a clear dynastic statement, with two granite obelisks from Egypt flanking its doorway; later, after the death of Augustus in 14 c.E., they could read the Res gestae, inscribed at his request on bronze columns or tablets and set up there as well, perhaps attached to the bases of the obelisks. ${ }^{130}$ Next to the Ara Pacis, and constructed at the same time, stood the Horologium-Solarium, a giant sundial. ${ }^{131}$ The sundial contained a political dimension, since the granite obelisk that served as its gnomon (pointer) was a royal monument of pharaonic Egypt, here the private possession of the princeps. ${ }^{132}$ To reinforce this point, the obelisk was dedicated in 10 B.C.E. to Sol as part of the spoils of Egypt. ${ }^{133}$ Sol was equated with Helios/Apollo; as Augustus's patron divinity, Apollo had helped him to victory at Actium, and Sol/ Apollo was also the god of the new saeculum. ${ }^{134}$ These elements carry perhaps a veiled claim to divine status as well, for Apollo was considered the father of Augustus, a tradition that has roots in Hellenistic ruler cult. ${ }^{135}$

In addition, Sol had a specifically Italic connection, since the god was considered the ancestor of the Latin race, following a tradition as old as the seventh century B.C.E. According to Hesiod (Theogony 1011-16), Circe, the daughter of Helios (Sol) bore two sons to Odysseus, Agrius and Latinus; the latter became the eponymous ancestor of the tribes of Latium. At Laurentum the Trojans established two altars to Helios when they landed in Italy (Dio 1.55.2). In addition, Varro considered Sol a Sabine god originally and equated him with Apollo (5.68). Augustus's dedication, therefore, accommodated the traditions of several Mediterranean cultures.

While it might seem strange to us that the west facade of the Altar of Augustan Peace faced the obelisk that commemorated Augustus's greatest military accomplishment, Stefan Weinstock and Erich Gruen (among others) have shown that for the Romans, "peace" really meant pacification: the successful outcome of war against one's enemies. ${ }^{136}$ Thus, peace and war are complementary, not diametrically opposed, concepts, and as a result, it was entirely appropriate in Roman terms that the Ara Pacis and Horologium-Solarium were linked.

The sundial marked the winter solstice under Capricorn, the sign under which Augustus had been conceived (64 B.C.E.) and had assumed the title of Augustus (January 17, 27 B.C.E.). Edmund Buchner has also argued that on September 23, the birthday of Augustus and the approximate date of the autumn equinox, the shadow of the gnomon would trace a line across the pavement of the sundial from west to east, pointing at sunset toward the open doorway framing the inner altar of the Ara Pacis, an opening flanked by the reliefs depicting the infant Romulus and the mature Numa. Augustus's birthday had already become a public festival and the occasion for a supplicatio after the conquest of Egypt, so the creation twenty years later of a cosmic clock that marked this date was both a scientific and a religious triumph celebrating a day that was 
already special. ${ }^{137}$ Given these emphases on significant dates, it may not be coincidental that the Ara Pacis was begun during the year in which Augustus reached the climacteric age of fifty.

What has not been emphasized in previous discussions, however, is that there are two equinoxes during the year, one in March as well as one in September, and that the shadow of the gnomon would have traced the same line across the pavement on each occasion. Ancient astrologers calculated that Romulus, too, had been born on one of the equinoxes, and thus the shadow of the gnomon marked his birthday as well as that of Augustus. ${ }^{138}$ But Numa may also have had an equinoctial birthday. According to tradition, Numa was born on the day Romulus founded Rome, and thus he was the first child of the first saeculum of Rome's existence. ${ }^{139}$ While the city's foundation date is traditionally considered to be the Parilia festival on April 21, the most learned of the Augustan calendars, the Fasti Praenestini, gives Rome's foundation as March 23, the approximate date of the spring equinox. ${ }^{140}$ If so, then Numa's putative birthday on Rome's foundation date also coincides with an equinox-three founders and rulers of Rome whose birthdays are marked by the march of the sun's shadow toward the Ara Pacis. We must not forget that Augustus's wife Livia, too, had a place among these special births: the Ara Pacis was dedicated in 9 B.c.E. on her fiftieth birthday, January 30 , a date that was also celebrated by a supplicatio to the imperium of Augustus as "guardian of the Roman people and the world."141 Further manipulation of the calendar allowed Augustus symbolically to "erase" the existence of his greatest enemy, Antony: after 30 в.C.E. his birthday was declared a dies vitiosus, when no public business could be transacted. ${ }^{142}$

It would seem, therefore, that the pairing of Numa and Romulus on the west side of the Ara Pacis was deliberately designed to make three points. First, these individuals illustrate two models of rulership, one militaristic and the other pacific. Second, they serve as foils to Augustus, individually presenting important qualities that are fully integrated in the career and personality of Augustus. ${ }^{143}$ Finally, the circumstances of their births connect with the birth of Augustus and bring cosmic time full circle to the return of the golden age, a central message of the Ara Pacis and of the Augustan principate in the years following the Secular Games of 17 B.C.E. ${ }^{144}$ As Livy puts it in his history of early Rome (1.21.5) $:{ }^{145}$ "Thus, two successive kings, each in his own way, one by war, the other by peace, increased the nation ... a nation not only strong, but tempered by the arts of war and peace." If Romulus and Numa represent the flip sides of war and peace, these two ancient city founders merge in the Ara Pacis in the figure of Augustus.

Paul Rehak has a Ph.D. from Bryn Mawr College and teaches classics and archaeology at the University of Kansas. He publishes in the areas of prehistoric Aegean iconography and Greek and Roman sculpture and is currently co-editor of book reviews for the American Journal of Archaeology [Department of Classics, Wescoe Hall, University of Kansas, Lawrence, Kans. 66045].

\section{Frequently Cited Sources}

ANRW: Aufstieg und Niedergang der römischen Welt (Berlin: Walter de Gruyter, 1972-).

Galinsky, Karl, Augustan Culture: An Interpretive Introduction (Princeton: Princeton University Press, 1996)

Holliday, Peter J., ed., Narrative and Event in Ancient Art (Cambridge: Cambridge University Press, 1993).

Kaiser Augustus: Mathias Hofter et al., eds., Kaiser Augustus und die verlorene Republik (Mainz: Philipp von Zabern, 1988).

Kleiner, Diana E. E., Roman Sculpture (New Haven: Yale University Press, 1992).

Koeppel, Gerhard, "Die historischen Reliefs der römischen Kaiserzeit V. Ara Pacis," pt. 1, Bonner Jahrbücher 187 (1987): 101-57.

LIMC: Lexicon Iconographicum Mythologiae Classicae (Zurich: Artemis, 1981-). LTUR: Lexicon Topographicum Urbis Romae, vols. 1-5 (Rome: Quasar, 19932000).

Weinstock, Stefan, "Pax and the Ara Pacis," Journal of Roman Studies 50 (1960): 44-58.

Zanker, Paul, The Power of Images in the Age of Augustus (Ann Arbor: University of Michigan Press, 1988).

\section{Notes}

This study grew out of two seminars on Roman imperial sculpture in 1998 and 1999. I am grateful to all the students for their insights and lively discussion, and especially to Eleni Eliades, who first seriously raised questions about the traditional interpretation of the "Aeneas" panel. I also thank Lawrence Richardson Jr. for subsequently allowing me to read a copy of an unpublished departmental paper in which he proposed the identification of Numa independently. Amy Vyas provided valuable research on the Roman calendar through a Dannenberg Fellowship from Duke University. Elizabeth Bartman, Mary T. Boatwright, Peter Burian, Nancy de Grummond, Melanie Grunow, Gerhard Koeppel, Nancy Ramage, Lawrence Richardson Jr., Brunilde S. Ridgway, Erika Simon, Steven Tuck, Annabel Wharton, John G. Younger, and the referees for the Art Bulletin made a number of helpful suggestions, although they do not necessarily agree with all my conclusions. Any errors of fact or interpretation are mine. The numbering of figures on the Ara Pacis follows Koeppel. An earlier version of this paper was presented under the same title at the annual meeting of the Archaeological Institute of America in Dallas, December 1999. Texts are from the Loeb Classical Library (Cambridge, Mass.: Harvard University Press); translations are my own.

1. The immense bibliography on the monument is summarized up to 1986 in Koeppel, with additions by Mario Torelli, "Pax Augusta, Ara," in LTUR, vol. 4 (1999), 70-74. Among the more recent studies, see, for example, Kleiner, 90-99; and Diane A. Conlin, The Artists of the Ara Pacis: The Process of Hellenisation in Roman Relief Sculpture (Chapel Hill: University of North Carolina Press, 1997). For brief overviews of the monument, see Lawrence Richardson Jr., "Pax Augusta, Ara," A New Topographical Dictionary of Ancient Rome (Baltimore: Johns Hopkins University Press, 1992), 287-89; Amanda Claridge, Rome: An Oxford Archaeological Guide (Oxford: Oxford University Press, 1998), 184-90. For a useful introduction, see James C. Anderson, "The Ara Pacis Augustae: Legends, Facts and Flights of Fancy," in The Shapes of City Life in Rome and Pompeii: Essays in Honor of Lawrence Richardson, jr. on the Occasion of His Retirement, ed. Mary T. Boatwright and Harry B. Evans (New Rochelle, N.Y.: Aristide D. Caratzas, 1998), 27-51.

2. Mario Torelli notes the janiform shape: Typology and Structure of Roman Historical Reliefs (Ann Arbor: University of Michigan Press, 1982), 32.

3. When the Ara Pacis was reconstructed, on Mussolini's instructions, it was moved considerably to the north of its original location and rotated 90 degrees counterclockwise to align with the mausoleum of Augustus. By convention, modern discussions of the structure refer to its original orientation. Several studies have pointed out inaccuracies in the 1930s reconstruction: Diane A. Conlin, "The Reconstruction of Antonia Minor on the Ara Pacis Augustae," Journal of Roman Archaeology 5 (1992): 209-15; and Gerhard Koeppel, "The Third Man: Restoration Problems on the North Frieze of the Ara Pacis Augustae," Journal of Roman Archaeology 5 (1992): 216-17.

4. Richard G. Tansey and Fred S. Kleiner, Gardiner's Art through the Ages, 10th ed. (Fort Worth, Tex.: Harcourt Brace, 1996), for example, devotes sixty-nine column lines and three illustrations to the Ara Pacis; twenty-four lines and one illustration to the Forum of Augustus. On the forum, see Valentin Kockel, "Forum Augusti," in LTUR, vol. 2 (1995), 289-95; Martin Spannagel, Exemplaria Principis: Untersuchungen zu Entstehung und Ausstattung des Augustusforums, Archäologie und Geschichte, vol. 9 (Heidelberg: Archäologie und Geschichte, 1999). Augustus also identified himself closely with the temple of Apollo Palatinus: Barbara Kellum, "Sculptural Programs and Propaganda: The Temple of Apollo on the Palatine," in The Age of Augustus, ed. Rolf Winkes (Louvain-la-Neuve: Institut Supérieur d'Archéologie de l'Histoire de l'Art, Collège Érasme, 1985), 169-76; Eckard Lefèvre, Das 
Bild-Programm des Apollo-Tempels auf dem Palatin, Xenia, 24 (Konstanz: Universitätsverlag Konstanz, 1989); and Manuel Royo, Domus Imperatoriae: Topogra phie, formation et imaginaire des palais impériaux du Palatin, Bibliothèque des Écoles Françaises d'Athènes et de Rome, 303 (Paris: Bibliothèque des Écoles Françaises d'Athènes et de Rome, 1999), passim.

5 . The original dimensions of the relief were 61 inches $(1.55$ meters) in height and 96 inches (2.44 meters) in width. Its left half was discovered in 1859, the right in 1903. Unlike some Ara Pacis reliefs recovered earlier, these fragments were not subjected to excessive restoration. E. Petersen had called the figure subsequently thought of as Aeneas the Genius Senatus, with the Genius Populi Romani behind him: "Funde," Römische Mitteilungen 18 (1903): 332-33. For the earliest interpretation of the two halves of the relief as the sacrifice of Aeneas, see Johannes Sieveking, "Zur Ara Pacis Augustae," Jah reshefte des Österreichischen archäologischen Instituts in Wien 10 (1907): 175-99, fig. 58, esp. 187.

6. Discussions of the relief include Franz Studniczka, "Zur Ara Pacis," Abhandlungen der Sächsischen Akademie der Wissenschaften zu Leipzig 27 (1909); Lily Ross Taylor, The Divinity of the Roman Emperor (Middletown, Conn: American Philological Association, 1931); Domenico Mustilli, "L'arte Augustea," in Augustus: Studi in occasione del Bimillenario Augusteo (Rome: Accademia Nazionale dei Lincei, 1938), 320-21, pl. between 322 and 323; Giuseppe Moretti, Ara Pacis Augustae (Rome: Libreria dello Stato, 1948), 153-57, 21 , pl. B (left half of scene), 35, pl. C (right half), pls. xv (above), xxxix (detail of body of "Aeneas"), xIx (detail of head), xx (detail of head of "Achates"); Inez Scott Ryberg, "The Procession of the Ara Pacis," Memoirs of the American Academy in Rome 19 (1949): 80-81, fig. 1; Jocelyn Toynbee, "The Ara Pacis Reconsidered and Historical Art in Roman Italy," Proceedings of the Britis Academy 39 (1953): 77-78, pl. xv; Ryberg, The Rites of the State Religion in Roman Art, Memoirs of the American Academy in Rome, vol. 22 (Rome: American Academy in Rome, 1955), 40-41, pl. x, fig. 21; Weinstock, esp. 56-58, pl. vi.1; Ernst Nash, A Pictorial Dictionary of Ancient Rome, vol. 1 (New York: Praeger 1961-62), 69, fig. 66; Erika Simon, in Wolfgang Helbig, Führer durch die offentlichen Sammlungen Klassischer Altertümer in Rom, 4th ed. (Tübingen: G Wasmuth, 1963-72), vol. 2, 687-89, no. 1937; idem, Ara Pacis Augustae (Greenwich, Conn.: New York Graphic Society, 1968), 23-24, pl. 25; Karl Galinsky, Aeneas, Sicily, and Rome (Princeton: Princeton University Press, 1969), 199-200, fig. 8; John Pollini, "Studies in Augustan 'Historical' Reliefs," Ph.D. diss., University of California, Berkeley, 1978, 128-29; Fulvio Canciani, "Aineias," in $L I M C$, vol. 1, pt. 1 (1981), 391, no. 165, vol. 1, pt. 2 (1993) (plates), pl. 307 (=Aineias 165); Torelli (as in n. 2), 37-38; Eugenio La Rocca Ara Pacis Augustae (Rome: L'Erma di Bretschneider, 1983), 40-43; Erika Simon, Augustus: Kunst und Leben in Rom um die Zeitenwende (Munich: Hirmer, 1986), 42, fig. 40; Gunar Friebergs, C. Scott Littleton, and Udo Strutynski, "Indo-European Tripartition and the Ara Pacis Augustae," Numen 33, no. 1 (1986): 3-32, esp. 9 and pl. 5; Koeppel, 110-11, no. 2 (Aeneas in Lavinium) 111, fig. 2; Zanker, 203-5, fig. 157; Salvatore Settis, "Die Ara Pacis," in Kaiser Augustus, 412-13, fig. 189; Peter J. Holliday, "Time, History and Ritual on the Ara Pacis Augustae," Art Bulletin 72 (1990): 542-57, esp. 549-50, fig. 9; C. Brian Rose, "Princes and Barbarians on the Ara Pacis," American Journal of Archaeology 94 (1990): 453-67, reprinted in Eve D'Ambra, ed., Roman Art in Context: An Anthology (Englewood Cliffs, N.J.: Prentice-Hall, 1993), 53-74 Richard Gordon, "The Veil of Power: Emperors, Sacrifices, and Benefactors," in Pagan Priests: Religion and Power in the Ancient World, ed. Mary Beard and John North (Ithaca, N.Y.: Cornell University Press, 1990), 201-37, esp. 20911, fig. 23; Jás Elsner, "Cult and Sculpture: Sacrifice in the Ara Pacis Augustae," Journal of Roman Studies 81 (1991): 50-61; Kleiner, 93, 96, fig. 78; David Castriota, The Ara Pacis Augustae and the Imagery of Abundance in Later Greek and Early Roman Imperial Art (Princeton: Princeton University Press, 1995), 154, 162, pl. 45; Ann Kuttner, Dynasty and Empire in the Age of Augustus: The Case of the Boscoreale Cups (Berkeley: University of California Press, 1995), fig. 99; Elsner, Art and the Roman Viewer (Cambridge: Cambridge University Press, 1995), 195-99, fig. 32; Galinsky, 107, 109, fig. 43; Rose, Dynastic Commemoration and Imperial Portraiture in the Julio-Claudian Period (Cambridge: Cambridge University Press, 1997), 16, pl. 110; and Torelli (as in n. 1). For color illustration of the central section of the relief, see Robert Turcan, L'art romain dans l'histoire: Six siècles d'expressions de la romanité (Paris: Flammarion, 1995), 99, fig. 114 .

7. The head of one figure, formerly assigned to the far right corner of the panel, is now thought to belong to the northern relief that depicts Roma on the east end of the monument and may represent the head of Honos or the Genius Populi Romani: Simon, 1968 (as in n. 6), pl. 29; Settis (as in n. 6), 412 Koeppel, 110, 115, no. 3, fig. 7; and Kuttner (as in n. 6), 20.

8. Ryberg, 1955 (as in n. 6), remains the basic study of Roman sacrificial iconography. For altars to the Lares Augusti, the decoration of which often includes sacrificial scenes, see Michael Hano, "À l'origine du culte impérial Les autels des Lares Augusti; Recherches sur les thèmes iconographiques et leur signification," in $A N R W$, vol. 2 (1986), fasc. 16, sec. 3, 2333-81. See also Anne V. Siebert, Instrumenta Sacra: Untersuchungen zu römischen Opfer-, Kultund Priestergeräten, Religionsgeschichtliche Versuche und Vorarbeiten, vol. 44 (Berlin: Walter de Gruyter, 1999); Friederike Fless, Opferdiener und Kultmusiker auf stadtrömischen historischen Reliefs: Untersuchungen zur Ikonographie, Funktion und Benennung (Mainz: Philipp von Zabern, 1995).

9. Thus, an Antonine medallion depicting Aeneas, for example, has sometimes been adduced as a direct adaptation of the Ara Pacis panel. While the composition is similar, the figures differ from those on our relief: the sacrificing Aeneas is armored and wears a military cloak, while his young son behind him is a diminutive figure. The figures stand in front of a large tetrastyle temple. In any case, the medallion cannot be used as proof that the Ara Pacis relief represented Aeneas 150 years earlier: Enrico Paribeni, "Askanios," in $L I M C$, vol. 2, pt. 1 (1984), 860-63, esp. 861, no. 15 (=Aineias 172), vol. 2, pt. 2 (plates), 630, no. 15; Francesco Gnecchi, I Medaglioni Romani, vol. 2 (Milan: V. Hoepli, 1912), 37, no. 84, pl. 66.6; Ferdinando Castagnoli, Lavinium, vol. 1, Topografia generale, fonti e storia della ricerche (Rome: De Luca, 1972), 81, no. 182, fig. 88; and Weinstock, 58 and n. 137, pl. 7.9.

10. Pliny, Historia naturalis (NH) 34.23. Zanker, 203-4, makes the same comparison but characterizes this costume as one that gives "Aeneas" a "special dignity." See discussion by Emeline Hill Richardson, "The Types of Hellenistic Votive Bronzes from Central Italy," in Eius Virtutis Studiosi: Classical and Postclassical Studies in Memory of Frank Edward Brown (1908-1988), ed. Russell T. Scott and Ann R. Scott, Studies in the History of Art, vol. 23 (Washington, D.C.: National Gallery of Art, 1993), 281-301. In pose the Ara Pacis figure also recalls that of Nestor from the paintings in the François Tomb at Vulci (third quarter of the 4th century B.C.E.), notable in his dark red mantle over a white tunic; see Francesco Buranelli, La Tomba François di Vulci (Rome: Quasar, 1987); Mario Cristofani et al., Die Etrusker (Stuttgart: Belser, 1995), 66, color fig. C; Peter J. Holliday, "Narrative Structures in the François Tomb," in Holliday, 175-97.

11. Cf. the seated Zeus (figure 30) on the east frieze of the Parthenon: Martin Robertson and Alison Frantz, The Parthenon Frieze (Oxford: Phaidon Press, 1975); Ian Jenkins, The Parthenon Frieze (Austin: University of Texas Press, 1994), ill., 78-79.

12. LIMC, vol. 1, 401, no. 7, pl. 312 (=Aion 7); Andreas Alföldi, Aion in Mérida and Aphrodisias, Madrider Beiträge, vol. 6 (Mainz: Philipp von Zabern, 1979), 14-15, pls. 28, 29; R.R.R. Smith, Aphrodisias, vol. 1, The Monument of $C$. Julius Zoilos (Mainz: Philipp von Zabern, 1993), 45-48, figs. 8, 9, pls. 20, 21, 32

13. Older individuals include, in the south frieze, S-23 (a flamen), S-28 (Agrippa), and S-44 (an older man with an extremely large head). Many of the heads in the north frieze are restored, but N-39 represents a veiled old woman in low relief. She turns her head over her right shoulder, and two deeply cut naso-labial folds are visible even though the upper part of her face has sheared away.

14. Weinstock, 57, though Zanker, 204, identifies it as a spear in token of his rule.

15. Kleiner, 93, states, "Aeneas has a patera in his right hand and, with his left, he pours a libation on the altar." The first observation may be correct, though the wrist and hand are missing. The left hand, however, supports the staff and is nowhere near the altar. A patera is carved on the tympanum of the small shrine on the relief. One camillus in the north frieze, $\mathrm{N}-7$, also carries another (Koeppel, 128-29, no. 7, fig. 18), and paterae of two types are carved on the inner face of the precinct wall. Overall, paterae are the most frequently represented sacrificial vessels on the Ara Pacis.

16. The seer Helenus tells him to cover his head with his purple robe (amictus), not a toga, when he comes to establish altars (note the plural) on the shores of Italy (Aeneid [Aen.] 3.403-5): "quin ubi tranmissae steterint trans aequora classes / et positis aris iam vota in litore solves, / purpureo velare comas adopertus amictu.....

17. On the iconography of Aeneas, see Galinsky, 1969 (as in n. 6), passim; Canciani (as in n. 6); Zanker, 201-10; Kaiser Augustus, 411, fig. 190. A marble relief in London telescopes the events connected with Aeneas's arrival: sow, city, hero, and one of his ships are all present in the same scene: Settis (as in n. 6), 411, fig. 190; $L I M C$, vol. 1 , pt. 1 (1981), 391, no. 168 , pl. 307.

18. As described in, for example, Aen. 2.705-29. See Canciani (as in n. 6); Peter Aichholzer, Darstellungen römischer Sagen, University of Vienna, 1983 , 160; W. Fuchs, "Die Bildgeschichte der Flucht des Aeneas," in ANRW, vol. 1, fasc. 4 (1973), 615-32; Jacques Poucet, "La diffusion de la légende d'Énée en Italie centrale et ses rapports avec celle de Romulus," Les Études Classiques 57 (1989): 227-54; and Tim J. Cornell, The Beginnings of Rome: Italy and Rome from the Bronze Age to the Punic Wars (c. 1000-264 B.C.) (London: Routledge, 1995), 63-68. For examples on coins, see a denarius of Caesar of 46 B.C.E. with a clean-shaven, nude young Aeneas carrying the palladium in his right hand and supporting a bearded Anchises with veiled head on his shoulders (Galinsky, 1969 [as in n. 6], fig. 2; Zanker, 35, fig. 27) and the altar to the gens Augusta at Carthage (Louis Poinssot, L'autel de la Gens augusta à Carthage, Notes et documents, 10 [Paris: Vuibert, 1929], 5-38, pls. 1-16; Ryberg, 1955 [as in n. 6], 89-90; Galinsky, 1969 [as in n. 6], 9, fig. 7). The mythological panels from the imperial cult complex at Aphrodisias also include this scene: R.R.R Smith, "Myth and Allegory in the Sebasteion," in Aphrodisias Papers, ed. Charlotte Roueché and Kenan T. Erim, Journal of Roman Archaeology, suppl. ser., no. 1 (Ann Arbor: [Editorial Committee of the Journal of Roman Archaeology], 1990), 98, fig. 9 (center). Smith notes that the woman in the background is Aphrodite escorting Aeneas, not his wife Creusa. Aeneas's rescue of his father and son are usually understood as an exemplum pietatis, a theme that has no obvious connection with the Ara Pacis. Recently, Belinda O. Aicher has suggested that the bearded figure traditionally identified as Mars on the Sorrento base is actually Aeneas in armor: "The Sorrento Base and the Figure of Mars," Archaeological News 15 (1990): 11-16. A late Republican cylindrical base at Cività Castellana is carved with a bearded sacrificing male in armor who is sometimes identified as Aeneas, though other identifi- 
cations are possible: Reinhard Herbig, "Römische Basis in Cività Castellana," Römische Mitteilungen 42 (1927): 129-47, suppl. pls. 15-19; Henner von Hesberg, "Archäologische Denkmäler zu den römischen Göttergestalten," in $A N R W$, vol. 2, fasc. 17 (1981), sec. 2, 1048-51; Kleiner, 51, 52, fig. 32.

19. Via dell'Abondanza painting at Pompeii: Zanker, 202, fig. 156a; Jean Gagé, "Romulus-Augustus," Mélanges de l'Ecole Française de Rome 47 (1930): 141-42, fig. 3. A painted parody of the group exists; for recent discussion, see Mariette De Vos, "La fuga di Enea in pitture del I secolo d.C.," Kölner Jahrbuch für Vor- und Frühgeschichte 24 (1991): 113-23. Here, a distinctly youthful Aeneas in armor and (anachronistic) patrician Roman shoes carries his old father and leads his small son, the latter dressed as a Phrygian shepherd and holding the pedum (shepherd's staff). The base of a (missing) statue of Aeneas, one of a pair of pendant works discovered at the Eumachia Building in Pompeii, probably also showed the same composition as the one in the Forum of Augustus because the base reproduces the elogium from the Forum of Augustus in Rome: Johannes A. Overbeck, Pompeji (Leipzig: W. Engelmann, 1866 ), vol. 1, 132. This group was duplicated in the Julio-Claudian period for a sculptural ensemble in the forum at Mérida, Spain, the decoration of which is based on that of the Forum of Augustus in Rome: José Luis de la Barrera Anton and Walter Trillmich, "Eine Wiederholung der Aeneas-Gruppe vom Forum Augustum samt ihrer Inschrift in Mérida (Spanien)," Römische Mittei lungen 103 (1996): 119-38.

20. Harold Mattingly, The Roman Imperial Coinage, vol. 1 (London: Spink and Son, 1923, rev. ed. 1984), pl. viI.116; idem, Coins of the Roman Empire in the British Museum (London: Longmans, 1923), 153, nos. 41-43, 157, no. 69, pls. 28.6, 28.9, 29.14. The temple has not been excavated: Duncan Fishwick, "On the Temple of Divus Augustus," Phoenix 46 (1992): 235-55; Mario Torelli, "Augustus, Divus, Templum (novum), Aedes," in LTUR, vol. 1 (1993), 14546; Richardson (as in n. 1), s.v. "Augustus, Divus, Templum," 45-46.

21. Weinstock, 57-58.

22. The Ara Pacis Augustae and the Ara Fortunae Reducis before it both commemorated returns of Augustus to Rome after extended absences in the provinces. These returns are not really parallel to Aeneas's initial arrival in Italy.

23. Simon, 1968 (as in n. 6), 23; Zanker, 204, concurs.

24. Augustus, Res gestae 6.35: "While I was in the process of administering my thirteenth consulship, the senate and the equestrian order and all the Roman people gave me the title 'father of the country' and decreed that it be inscribed on the vestibule of my residence and in the Senate House and in the Forum of Augustus on the base of the four-horse chariot that had been set up there for me by senatorial decree [tertium decimum consulatum cum gerebam, senatus et equester ordo populusque Romanus universus appellavit me patrem patriae idque in vestibulo aedium mearum inscribendum esse atque in curia et in foro Aug. sub quadrigis, quae mihi ex s.c. positae sunt, decrevit]."

25. Achates: Studniczka (as in n. 6), 923; Moretti (as in n. 6), 153; Toynbee (as in n. 6), 78; Koeppel, 111, no. 4; and Richard Billows, "The Religious Procession of the Ara Pacis Augustae: Augustus' Supplicatio in 13 B.c.," Journal of Roman Archaeology 6 (1993): 80-92, esp. 87 n. 23.

Iulus/Ascanius: Weinstock, 57; Simon, 1968 (as in n. 6), 23; Torelli (as in n. 2), 37; La Rocca (as in n. 6), 40; and Kleiner, 93, notes that he is an adult, but refers to him as Iulus/Ascanius. Torelli (as in n. 1), 71: "Aeneas sacrificing to the Penates at Lavinium assisted by Iulus-Ascanius." In an attempt to resolve the problem, Zanker, 204, calls the figure Ascanius who is "now grown into a youth." He identifies the figure's stick as a "shepherd's staff," but it lacks the curve at the top and is too long. Rose instead identifies the figure on the far right as Achates and the camillus next to the altar as Aeneas's son, despite the presence of an equally youthful victimarius in the scene: Rose, 1990 (as in n. 6), 462, 465-66; idem, 1997 (as in n. 6), 16

26. Iulus/Ascanius: G. Bermond Montanari, "Ascanio," in Enciclopedia dell'arte antica, classica e orientale, vol. 1 (Rome: Istituto della Enciclopedia Italiana, 1958), 704-5; and Paribeni (as in n. 9), vol. 2, pt. 2 (plates), 629-32.

27. For the position of the staff, cf. the figure of a hero on a relief panel of the Memmius Monument at Ephesos: Mario Torelli, "Il monumento efesino di Memmius: Un capolavoro dell'ideologia nobilare della fine della repubblica," in Il rango, il rito e l'immagine: Alle origini della rappresentazione storica Romana (Milan: Electa, 1997), 152-74, esp. 157, fig. 137.

28. No pig has survived among the animals depicted on the inner altar frieze; however, see Koeppel, 138-41.

29. Another garlanded attendant in a tunic in the north frieze, N-24, holds a similar guttus and has a mantele draped over the left arm: Koeppel, 131-32, no. 24, 133, fig. 26; Koeppel (as in n. 3) suggests that this foreground youth with frontal body may be a member of the imperial family. On the inner altar frieze one camillus holds a guttus (Koeppel, 138, no. 1, fig. 27), while his companion, a victimarius, holds a lanx at shoulder level (Koeppel, 138, no. 2 , fig. 27). Another attendant from this frieze holds a guttus and carries an acerra (Koeppel, 141, no. 15, 142, fig. 31). Cf. the youth with a tray of offerings on the Telephos frieze of the Pergamon Altar: Evamaria Schmidt, The Great Altar of Pergamon (Leipzig: VEB, 1962), pl. 67.

30. Five other figures on the Ara Pacis have been identified as possible camilli, one in the south frieze (S-10), three in the north frieze $(\mathrm{N}-7, \mathrm{~N}-24$, $\mathrm{N}-38$ ), and one on the frieze of the inner altar. On camilli, see esp. Fless (as in $\mathrm{n} .8)$.

31. La Rocca (as in n. 6), 42; Koeppel, 100, mentions the braid (Zopf). For comprehensive discussion, see Fless (as in n. 8), 38-43: "Long-haired minis- trants in tunics." In a recent investigation of the homoerotic scenes on the Warren Cup, a silver vessel he dates to the Augustan or early Julio-Claudian period, John Pollini has identified another youth with long hair at the back of the head (from a loosened braid?) as a male sex slave-hardly a likely identification for the figure on the Ara Pacis relief: "The Warren Cup: Homoerotic Love and Symposial Rhetoric in Silver," Art Bulletin 81 (1999): 21-52, esp. 27, fig. 9. Dyfri Williams, however, dates the vessel to the late Julio-Claudian period and identifies its probable place of manufacture as the eastern Mediterranean: “The Warren Cup,” Minerva 10, no. 4 (1999): 33-35, esp. fig. 5. Varro, De lingua latina 7.34 , also mentions the existence of female camillae.

32. A. Herrmann, "The Boy with the Jumping Weights," Bulletin of the Cleveland Museum of Art 80, no. 7 (1993): 299-323, esp. 304-7. I am grateful to Brunilde $\mathrm{S}$. Ridgway for calling this article to my attention.

33. See n. 25 above.

34. Suggested by C. Brian Rose. Since Rose proposes that "Aeneas" and "Achates" represent Augustus and Agrippa (1990 [as in n. 6], 462 and n. 55), he wants "Julus" as a reference to Gaius Caesar, whom he identifies as a youth in the north frieze, N-38, though as he himself notes, the figures are of different heights, and therefore not the same age (ibid., 466, figs. 11, 12 for good detail, and 1997 [as in n. 6], 16). Barbara Kellum goes even further; she claims that there is a "remarkable resemblance between the emperor's young son and the figure of Iulus, who serves his father Aeneas": "What We See and What We Don't See: Narrative Structure and the Ara Pacis Augustae," Art History 17 (1994): 38. It is important to note that the mantele used by camilli has a flocked surface as well as fringe, and thus is a different garment from the plain cloth with a fringed border that N-38 wears over one shoulder. "Gaius" also lacks a garland, and the guttus in his right hand is a hypothetical reconstruction. In short, there is no reason to connect N-38 with the child on the end panel. On the iconography of Gaius, see John Pollini, The Portraiture of Gaius and Lucius Caesar (New York: Fordham University Press, 1987).

35. Ryberg, 1949 (as in n. 6), 80, is confident that this is a pregnant sow (feta sus), but the missing portion of the relief makes it impossible to be sure.

36. See Moretti (as in n. 6), pl. xv, where two of the teats are outlined against the leg of the attendant in the background. I thank Gerhard Koeppel and Melanie Grunow for emphasizing this point.

37. Kleiner, 48-51, fig. 31; Ann Kuttner, "Some New Grounds for Narrative: Marcus Antonius' Base (The Ara Domitti [sic] Ahenobarbi) and Republican Biographies," in Holliday, 198-229.

38. Kleiner 142, fig. 117

39. Belvedere Altar, Museo Gregoriano Profano, Vatican, no. 1115: Giulio E. Rizzo, "Leggende latine antichissime," Römische Mitteilungen 21 (1906): 300 (Virgil and Aeneas); L. R. Taylor, "The Mother of the Lares," American Journal of Archaeology 29 (1925): 308-9; Jean Gagé, "Un thème de l'art impérial romain: La Victoire d'Auguste," Mélanges de l'École Française de Rome 49 (1932): 63; Ryberg, 1955 (as in n. 6), 58-59; Werner Hermann, Römische Götteraltäre (Kallmünz: M. Lassleben, 1961), 154, no. 1A; Paul Zanker, "Die Larenaltar im Belvedere des Vatikans," Römische Mitteilungen 76 (1969): 205-18; Galinsky, 1969 (as in n. 6), 24-25, fig. 18 (Galinsky interprets the prophet as the one reading to Venus from the scroll of fate in Aen. 1.261-96, unnecessarily conflating two stories); E. L. Harrison, "The Seated Figure on the Belvedere Altar," Revue Archéologique, 1971: 71-73 (Helenus and Aeneas); Andreas Alföldi, Die Zwei Lorbeerbäume des Augustus (Bonn: R. Habelt, 1973), 30 n. 19 Augusto Fraschetti, "La mort d'Agrippa et l'autel du Belvédère: Un certain type d'hommage," Mélanges de l'École Française de Rome 92 (1980): 957-76, esp. 964-67, fig. 3 (detail of scene); Pollini (as in n. 6), 299-304; Mark Fullerton, "The Domus Augusti in Imperial Iconography of 13-12 в.c.," in American Journal of Archaeology 89 (1985): 473-83, esp. 482, pl. 57, fig. 1; Hano (as in n. 8), esp. 2344-45, no. 10, pl. XII.26; Kaiser Augustus, 394-96, no. 223, ills., 395; Kleiner, 102-3; Galinsky, 319, 321, fig. 150, compares the figure to that of the sacrificant in the "Aeneas" panel, but it is actually much closer to that of Faustulus in the Romulus panel; Mary Beard, John North, and Simon Price, eds., Religions of Rome (New York: Cambridge University Press, 1998), 187, fig. 4.3.

40. Pigs, however, were offered in private cult to the household gods.

41. On the Secular Games, see esp. Zanker, 167-72; Galinsky, 100-106; John F. Hall, "The saeculum novum of Augustus and Its Etruscan Antecedents," in $A N R W$, vol. 2, fasc. 16, sec. 3, 2564-89.

42. Mattingly, 1923/1984 (as in n. 20), 19, nos. 96, 97, pls. 3.16, 3.17; C.H.V. Sutherland, The Roman Imperial Coinage, vol. 1, rev. ed. (London: Spinks and Son, 1984), 68, no. 363, pl. 7. The coin carries the head of Augustus on the obverse; the reverse shows the sacrificial scene with the legend FOEDUS $\mathrm{P}$ (opuli) R(omani) QVM [GABINIs]: W. H. Gross, "Ways and Roundabout Ways in the Propaganda of an Unpopular Ideology," in The Age of Augustus, ed. Rolf Winkes (Louvain-la-Neuve: Institut Supérieur d'Archéologie de l'Histoire de l'Art, Collège Érasme, 1985), 29-50, esp. 41 and n. 69; Zanker, 169, fig. 134. The moneyers responsible for the coin, C. Antistius Vetus and C. Antistius Reginus, traced their ancestry back to Gabii. Gross considers this an example of the way Imperial and Republican themes were sometimes combined even in official coinage.

43. The depiction of the shrine is similar to representations on other Augustan reliefs and paintings. Cf. the small background structures on a decorative relief with a pastoral scene (Munich, Glyptothek, no. 455), a "Grimani" relief from Palestrina (Vienna, Kunsthistorisches Museum, no. AS 
1.604), and a painting from Alexandria: Wiktor A. Daszewski and Ahmed Abd-el-Fattah, "A Hellenistic Painting from Alexandria with Landscape Elements," in Akten des XIII. Internationalen Kongresses für klassische Archäologie Berlin 1988 (Mainz: Philipp von Zabern, 1990), 441-42.

44. Zanker, 205, sees this as a reference to the aurea templa in Rome built or restored by Augustus. Cf. Pierre Gros, Aurea Templa: Recherches sur l'architecture religieuse de Rome à l'époque d'Auguste, Bibliothèque des Écoles Françaises d'Athènes et de Rome, 231 (Rome: École Française de Rome, 1976).

45. The carving of the wickerwork pattern occurs only in the center, not at the sides, indicating areas where the relief probably remains unfinished. This cannot simply be a barrier that closes off the central opening, since there is a vertical groove in the middle that creates the impression of two gates. The closest parallel for the wickerwork pattern occurs on the relief over the Porta Marzia at Perugia (2nd century B.C.E.). Over the arched gateway appear five figures in niches framed by pilasters, set behind a balustrade carved like wickerwork with a surmounting horizontal rail: Cristofani et al. (as in $\mathrm{n}$. 10), 35 , color fig.

46. Dionysios of Halikarnassos 1.68 .2 says the figures in the temple of the Penates on the Velia are seated, holding spears, but he specifically states that they are youths (neaniai), which our bearded figures are not. He adds, "And we have seen many other statues of these divinities in ancient temples and in all of them they appear as two young men in military outfits." On the Penates, see Gerhard Radke, "Die dei penates und Vesta in Rom," in ANRW, vol. 2, fasc. 17, sec. 1, 343-73. The temple on the Ara Pacis relief has been discussed recently by Maria A. Tomei, who identifies the shrine as the one to the Penates on the Velia: "A proposito della Velia," Römische Mitteilungen 101 (1994): 309-38, esp. 327-29, pls. 111.1 (Aeneas panel), 111.2 (detail of the shrine with the figures inside).

47. On the inner altar frieze, see Koeppel, 138-46; and Erwin Bielefeld, "Bemerkungen zu den kleinen Friesen am Altar der Ara Pacis Augustae," Römische Mitteilungen 73-74 (1966-67): 259-65. Elsner, 1995 (as in n. 6), 195, claims: "It [the relief] decorates the walls of the precinct within which the very ritual it portrays was enacted." Since this is incorrect, his entire theory of "deferral"- the lag between the killing of the animal and the offering of its entrails on the altar-is irrelevant. It also is not true that Roman altars were always associated with temples, as Elsner claims; the Ara Martis in the Campus Martius and the Ara Pacis itself are cases in point.

48. Res gestae 13: "aram pacis augustae Senatus pro reditu meo consacrari censuit ad Campum Martium, in qua magistratus et sacerdotes et virgines vestales anniversarium sacrificium facere iussit." Ovid, Fasti 1.709-10, mentions only a single victim, but does not say what it was. Another priesthood, the fratres arvales, also sacrificed at the Ara Pacis during the Julio-Claudian period. On the fratres arvales, see Varro 5.85 .

There has been little discussion about how an animal sacrifice could have taken place at the Ara Pacis, and it is difficult to envision. It would be virtually impossible to bring living victims up the steep steps to the small inner altar, where there is little space for the human participants and observers to stand any victims killed must have been put to death outside the precinct wall. These issues merit further study. Elsner, 1991 (as in n. 6), 54, argues that the recipient of the sacrifice is ambiguous, because there is no temple near the altar. The sacrifice, however, is on behalf of Augustus, in honor of his return ("pro reditu meo") from the western provinces in 13 B.C.E.

49. Ryberg, 1955 (as in n. 6), 42, points out that "the association of a ram, steer and heifer as a triple offering is unparalleled in Roman religion"; as Weinstock, 54 and n. 118, has noted, however, the sex of the animals is not clear. In 38 C.E., the fratres arvales sacrificed a cow at the Ara Pacis on its foundation date, July 4, but we do not know how early this practice began: John Scheid and Henri Broise, "Deux nouveaux fragments des actes des frères arvales de l'année 38 ap. J.-C.," Mélanges de l'École Française de Rome 92 (1980): 215-48.

50. Ferdinando Castagnoli, "La leggenda di Enea nel Lazio," Studi Romani 30 (1982): 1-15; and Tim Cornell, "Aeneas' Arrival in Italy," Liverpool Classical Monthly 2 (1977): 77-83. Versions of these stories also survive in fragments of Dio Cassius preserved by Tzetzes in Lycophron, Alexandra, v. 1232. The ancient sources are collected by Castagnoli (as in n. 9), 59-64.

51. "signa tibi dicam, tu condita mente teneto. / cum tibi sollicito secreti ad fluminis undam / littoreis ingens inventa sub ilicibus sus / triginta capitum fetus enixa iacebit, / alba, solo recubans, albi circum ubera nati, / is locus urbis erit, requies ea certa laborum."

52. "Ecce autem subitum atque oculis mirabile monstrum, candida per silvam cum fetu concolor albo / procubit viridique in litore conspicitur sus. / quam pius Aeneas tibi enim, tibi, maxima Iuno, / mactat sacra ferens et cum grege sistit ad aram."

53. Gabriella Vanotti, L'altro Enea: La testimonianza di Dionigi di Alicarmasso (Rome: Problemi e Ricerche di Storia Antica, 1995), 66-68.

54. Dion. Hal. 1.55.4. There is a textual problem at this point, as no sibyl of Erythrae on Mt. Ida is mentioned by other ancient sources.

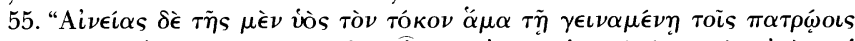

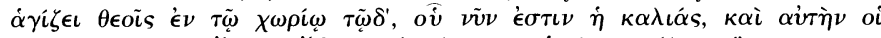

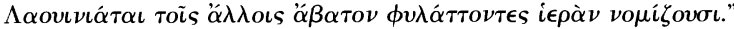

56. "oppidum quod primum conditum in Latio stirpis Romanae, Lavinium: nam ibi dii Penates nostri. Hoc a Latini filia, quae coniuncta Aeneae, Lavinia, appellatu(m). Hinc post triginta annos oppidum alterum conditur, Alba; id $\mathrm{ab}$ sue alba nominatum. Haec e navi Aeneae cum $\mathrm{fu}(\mathrm{g})$ isset Lavinium, triginta parit porcos; ex hoc prodigio post Lavinium conditum annis triginta haec urbs facta, propter colorem suis et loci naturam Alba Longa dicta."

57. Servius, ad Aen. 3.391, says that the number thirty symbolizes the number of years that Ascanius would rule.

58. La Rocca (as in n. 6), 40, tries, however: "Also lacking from the panel are the thirty piglets, surely to avoid an excessive crowding of the compositon." He sidesteps the issue of the missing piglets: "The depiction on the relief does not follow the Virgilian source precisely, but rather a variant handed down by Dionysios of Halikarnassos." Cf. Kleiner, 93: "Vergil's poem is not fully reproduced in this panel. Instead the scene seems to be closer to a version of the story handed down by Dionysios of Halikarnassos." See also Dominique Briquel, "L'oiseau ominal, la louve de Mars, la truie féconde," Mélanges de l'École Française de Rome 88 (1976): 31-50.

59. See above at $n$. 39. The white sow and her piglets are still a feature of visual renderings of the story as late as the 5th century C.E., as the illustration in the Vatican Virgil shows: Johannes De Wit, Die Miniaturen des Vergilius Vaticanus (Amsterdam: Swets en Zeitlinger, 1959), pl. 25.3.

60 . Weinstock, 56-58. This novel argument has never been widely accepted, but it deserves to be read.

61. Our major sources on Numa are Livy and Dionysios of Halikarnassos, writing in the Augustan period, and Plutarch and Dio Cassius, in the mid-2nd and early 3rd century C.E., respectively. For discussion, see esp. Konrad Glaser, "Numa Pompilius," in Paulys Real-Encyclopädie der classischen Altertumswissenschaft (RE), vol. 17, pt. 1 (Stuttgart: J. B. Metzler, 1936), 1242-52; Anna Longo, "Numa Pompilius," in Enciclopedia dell'arte antica, vol. 5 (Rome: Istituto Poligrafico dello Stato, 1963), 581-82.

62. Louise A. Holland, Janus and the Bridge (Rome: American Academy in Rome, 1961).

63. Festus 372M (510L): "tunc [in the spring] rem divinam instituerit Marti Numa Pompilius pacis concordia obtinendae gratia inter Sabinos Romanosque." Cf. Stefan Weinstock, Divus Julius (Oxford: Clarendon Press, 1971), 261 n. 5. On the Ara Martis, see Richardson (as in n. 1), s.v. "Mars, Ara," 245; Filippo Coarelli, "Mars, Ara," in LTUR, vol. 3 (1996), 223-26.

64. Fetial Law of Numa: Dion. Hal. 2.72.1-9. Cf. Cicero, De officiis 1.36, 3.108; idem, De legibus 3.9; Varro, De lingua latina 5.86; Plutarch (Plut.), Numa 12.3-7; idem, Camillus 18. Livy 1.20.4 alludes to them but does not name them until 1.24.7-9 and 1.32.9, when he describes their role before the battle between the Horatii and Curiatii during the reign of Tullius Hostilius. See also Robert M. Ogilvie, Commentary on Livy (Oxford: Clarendon Press, 1965), 131. Cicero also cites a variant tradition that the Fetial Law was established by King Tullius Hostilius during the Etruscan period: De republica (De rep.) 2.17 [31]. See also Ernst Samter, "Fetiales," in RE, vol. 6 (1909), 2259-65; Georg Wissowa, Religion und Kultus der Römer, Handbuch der Altertumswissenschaft, 2d. ed. (Munich: C. H. Beck, 1912; reprint, 1971), 550-54; Jean Bayet, "Le rite fécial et la cornouiller magique," Mélanges de l'École Française de Rome 52 (1935): 29-76, reprinted in Croyances et rites dans la Rome Antique (Paris: Payot, 1971), 9-43; Kurt Latte, Römische Religionsgeschichte, Handbuch der Altertumswissenschaft, vol. 4 (Munich: C. H. Beck, 1960), 121-24; Jörg Rüpke, Domi militiae: Die religiöse Konstruktion des Krieges in Rom (Stuttgart: F. Steiner, 1990), 97-117; André Magdelain, "Quirinus et le droit (spolia opima, ius fetiale, ius quiritium)," Mélanges de l'École Française de Rome 96 (1984): 195-237; Mauro Mantovani, Bellum iustum: Die Idee des gerechten Krieges in der römischen Kaiserzeit (Bern: Peter Lang, 1990).

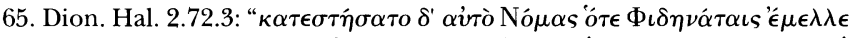

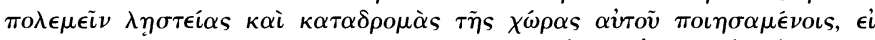

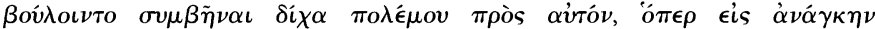
$\kappa \alpha \tau \alpha \sigma \tau \alpha \dot{\nu} \tau \epsilon \epsilon$ ' $\epsilon \pi \circ i \eta \sigma \alpha \nu$ " (Numa established it [the Fetial Law] when he was about to wage war against the inhabitants of Fidenae, who had made attempts by thefts and incursions, to see if they would come to an agreement with him without war. And constrained by necessity, they did so).

66. G. Burck, "Altrom im Kriege," Die Antike 16 (1940): 216-26; William V. Harris, War and Imperialism in Republican Rome, 327-70 B.C. (Oxford: Clarendon Press, 1979), 166-75, 269-79; Thomas Wiedemann argues that the ceremony was an innovation by Octavian, which seems unlikely: "The Fetiales: A Reconsideration," Classical Quarterly 36 (1986): 478-90.

67. On the columna bellica, see Richardson (as in n. 1), s.v. "columna bellica," 94; Eugenio La Rocca, "Columna Bellica," in LTUR, vol. 1 (1993), 300-301; idem, "Due monumenti a pianta circolare in circo Flaminio: Il perirrhanterion e la columna Bellica," in Scott and Scott, eds. (as in n. 10), 17-29.

68. See above at n. 42. The emperor Claudius, who was scrupulous about observing Roman religious traditions, sacrificed a sow in the Roman Forum whenever he made a peace treaty with a foreign power: Suetonius (Suet.), Claudius 25.12: "cum regibus foedus in foro icit, porca caesa, ac vetere fetialium praefatione adhibita."

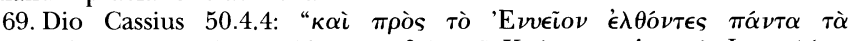

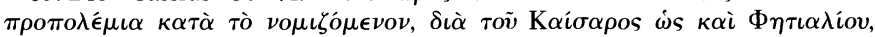
Ł̇Toí $\sigma \alpha \nu$." Cf. Livy 1.32.5-14; Ovid, Fasti 6.205-7; Augustus, Res gestae 4.7. This scene was actually reproduced (though not very precisely) in the Twentieth Century-Fox production of Cleopatra in 1963, with Octavian throwing the spear from the steps of the Senate House and killing the Egyptian ambassador.

70. Dio Cassius 50.4.5. See K. Scott, "The Political Propaganda of 44-30 B.C.," Memoirs of the American Academy in Rome 11 (1933): 7-49; Fritz Wurzel, Der Kriege gegen Antonius und Kleopatra in der Darstellung der augusteischen Dichter 
(Leipzig: R. Noske, 1941); Zanker, "Antony Betrayed by His Own Image," in Zanker, 57-65.

71. There may be another symbolic aspect to Octavian's casting of the fetial spear. A long tradition of "conquest by spear" was known to the Romans from the Greek world. When Alexander the Great invaded Asia, one of his first acts on landing was to throw a spear into the continent as a symbol of his aspirations: Justin 11.5.10: "cum delati in continentem essent, primus Alexander iaculum velut in hostilem terram iecit." Cf. Diodorus Siculus 17.17.2. See now Michael Zahrnt, "Alexanders Übergang über den Hellespont," Chiron 26 (1996): 129-47.

72. Various traditions exist about Numa's children-that he had a single daughter, or a daughter and four sons: Dion. Hal. 2.76.5; Plut., Numa 8.9, 21.1-2. See also Timothy P. Wiseman, "Legendary Genealogies in LateRepublican Rome," Greece and Rome 21 (1974): 153-64, esp. 154-55.

73. Romulus relief: Koeppel, 108-10, fig. 1. Recently, Castriota (as in n. 6), 154-58, esp. 155, has suggested that Faustulus in the relief is really King Numitor, grandfather of Romulus and Remus. See also Danielle Porte, "Romulus-Quirinus, prince et dieu, dieu des princes: Étude sur le personnage de Quirinus et sur son évolution, des origines à Auguste," in $A N R W$, vol. 2 (1981), fasc. 17, sec. 1, 300-342.

74. Romulus: "Quin et avo comitem see Mavortius addet / Romulus, Assaraci quem sanginis Ilia mater / educet. viden, ut geminae stant vertice cristae / et pater ipse suo superum iam signat honore? / en huius, nate, auspiciis illa incluta Roma / imperium terris, animos aequabit Olympo, / septemque una sibi muro circumdabit arces, / felix prole virum...." Augustus: "huc geminas nunc flecte acies, hanc aspice gentem / Romanosque tuos. hic Caesar et omnis Iuli / progenies, magnum caeli ventura sub axem. / hic vir, hic est, tibi quem promitti saepius audis, / Augustus Caesar, divi genus, aurea condet / saecula qui rursus Latio regnata per arva / Saturno quondam, super et Garamantas et Indos / proferet imperium (iacet extra sidera tellus, / extra anni solisque vias, ubi caelifer Atlas / axem umero torquet stellis ardentibus aptum); / huius in adventum iam nunc et Caspia regna / responsis horrent divum et Maeotia tellus, / et septemgemini turbant trepida ostia Nili." Numa: "Quis procul, ille autem ramis insignis olivae / sacra ferens? nosco crinis incanaque menta / regis Romani, primam qui legibus urbem / fundabit, curibus parvis et paupere terra / missis in imperium magnum."

In discussing this passage by Virgil (but without reference to the Ara Pacis), K. Scott, "The Identification of Augustus with Romulus-Quirinus," Transactions of the American Philological Association 56 (1925): 97, noted, "Vergil has tried to connect Augustus closely with Romulus and Numa and has tried to present them all as founder of Rome and its greatness, Romulus as the builder of the walls and the warrior, Numa as the lawgiver, and Augustus as the founder of the Golden Age of peace and prosperity through the virtues of both Romulus and Numa. If then we also find Livy assigning to Numa the honor of being called the second founder of Rome because of his legal and moral services, did not this act help to prepare the public mind for giving to Augustus the same title for the same merit?"

75. See n. 61 above.

76. Suet., Divus Julius 6.1: "For the family of the Marcii Reges [are descended] from Ancus Marcius, whose name was my mother's, while our Julian family [was descended] from Venus [ nam ab Anco Marcio sunt Marcii Reges, quo nomine mater fuit; a Venere Iulii, cuius gentis familia est nostra]."

77. Pliny, $N H$ 33.9-10, 33.24; Livy 1.34.6. The texts are assembled by Götz Lahusen, Schriftquellen zum römischen Bildnis, vol. 1, Textstellen: Von den Anfängen bis zum 3, Jahrhundert $n$. Chr. (Bremen: B. C. Heye, 1984), nos. 59, 71, 584. A bearded male head of the 2 nd century C.E. from the area of the House of the Vestals in the Roman Forum has sometimes been identified as Numa, perhaps based on the archaic statue on the Capitoline: Giovanni Becatti, "Ritratto di un vate antico," Bolletino d'Arte 34 (1949): 97-110. John Pollini suggests that a bearded head in Copenhagen of approximately the same date could represent an idealized portrait of Aeneas, but Numa seems equally a possibility: review of Die Bildnisse des Augustus, by Dietrich Boschung (Berlin: Gebrüder Mann, 1993), Art Bulletin 81 (1999): 723-35.

78. Cicero, De rep. 2.13.25-2.14.28, 5.3; De oratore (De orat.) 2.154 (cf. Tusculanae disputationes 4.1.3); and De natura deorum 3.5.

79. On Livy, bk. 1, see esp. Ogilvie (as in n. 64). The contrast between Romulus and Numa is very strongly drawn by Augustan authors, as noted by D. S. Levene, Religion in Livy, Mnemosyne, suppl., 127 (Leiden: E. J. Brill, 1993), 129-37.

80. See, for example, A. Burnett, "The Authority to Coin in the Late Republic and the Early Empire," Numismatic Circular 137 (1977): 37-63; Emanuela Fabbricotti, "Numa Pompilio e tre monetieri di età repubblicana," Annali, Instituto Italiano di Numismatica 15 (1968): 31-78; Patrizia Serafin Petrillo, "Le origini troiane e albane nella moneta di età repubblicana," in Alba Longa: Mito, Storia, Archeologia; Atti dell'Incontro di Studio Roma-Albano Laziale 27-29 gennaio 1994, ed. Anna Pasqualini (Rome: Istituto Italiano per la Storia Antica, 1996), 201-15. See also T. J. Luce, "Political Propaganda on Roman Republican Coins: Circa 92-82 B.C.," American Journal of Archaeology 72 (1968): 25-39.

81. Ernest Babelon, Description historique et chronologique des monnaies de la République romaine, vols. 1, 2 (Bologna: A. Forni, 1885; reprint, 1974), vol. 2 , 359, no. 6; Herbert A. Grueber, Coins of the Roman Republic in the British Museum, 2 vols. (London: Trustees of the British Museum, 1910), vol. 2, 311-12, nos. 733-38, pl. xcvi.3; Michael H. Crawford, Roman Republican
Coinage, vol. 1 (Cambridge: Cambridge University Press, 1974), 332, no. 334, pl. xuII, no. 334/1. The Pomponii claimed descent from Numa through his son Pompo: Plut., Numa 1.

82. Babelon (as in n. 81), vol. 2, 191, no. 18, 193, no. 20; Grueber (as in n. 81), vol. 1, 301, no. 2367, pl. xxxvi.10. The obverse shows two male heads, jugate and diademed, both facing to the right, one bearded (Numa) and one clean-shaven (Ancus Marcius); some of the coins carry the legend NVMA POMPILI ANCVS MARCI, confirming the identification. Since the family of Censorinus was the gens Marcia, descended from Numa through the wife of Ancus Marcius, the identification of the busts seems plausible.

83. Babelon (as in n. 81), vol. 2, 303 n. 30, 348, no. 8; Grueber (as in n. 81), vol. 2, 361, nos. 62, 63; Crawford (as in n. 81), 463, no. 446, pl. LIII, no. 446/1.

84. The tresviri were Cnaeus Calpurnius Piso, Lucius Naevius Surdinus, and Caius Plotius Rufus; the Pisones claimed descent from Numa through his son Calpus: Plut., Numa 21. Mattingly, 1923 (as in n. 20), 71, nos. 390-93; Sutherland (as in n. 42), 32, 33, 70, 71-72, nos. $390-96$, pl. 7, no. 395; Grueber (as in n. 81), vol. 2, 90, no. 4625; Babelon (as in n. 81), vol. 1, 306, no. 307, vol. 2, 91, nos. 293-95 (Piso), 249, nos. 7, 8 (Piso, Surdinus, Plotius), 327, nos. 17, 18 (Plotius); Anne S. Robertson, Roman Imperial Coins in the Hunter Coin Cabinet, University of Glasgow, vol. 1 (London: Oxford University Press, 1962), xxxiv-xxxv; Galinsky, 34-36, fig. 18. Galinsky has also argued that Numa was connected with Apollo, the theme of peace, and the Secular Games. In a review of Galinsky, Barbara Kellum noted, "The reciprocal relationship of the images on the coins underscores several of Galinsky's main themes even more strongly than he seems to realize. The affiliation between the Augustan present and the past was manifested on a coin where Numa was literally the 'flip' side of Augustus": "Re-viewing Augustan Culture," Journal of Roman Archaeology 11 (1998): 517-23, esp. 518.

85. Andrew Wallace-Hadrill, "Image and Authority in the Coinage of Augustus," Journal of Roman Studies 76 (1986): 66-87, esp. 82-83.

86. Livy 1.18.6-10; Plut., Numa 7.2; Dion. Hal. 2.60.2.

87. For example, he notes in Res gestae 1.5 that he refused the office of dictator when offered it, as well as the proposal to make him consul every year or for life.

88. Augustus, Res gestae 6.34: Augustus claims that he received absolute control of political affairs but transferred it back to the Senate and people ("per consensum universorum potitus rerum omnium, rem publicam ex mea potestate in senatus populique Romani arbitrium transtuli"). Cf. Suet., $A u-$ gustus (Aug.) 7; Florus 2.34.66; Dio 53.16.6-8. Romulus had founded Rome by augury, but Numa's ordination as king was actually confirmed by augury. Augustus repeatedly emphasized his seeking of divine approval, and Zanker has noted the creation of many images that show the emperor capite velato: Zanker, 126-29, cf. 162-64. For examples, see Boschung (as in n. 77).

89. Ennius, Annales frag. 155 (Skutsch): "augusto augurio postquam incluta condita Romast." See Francis Haverfield, "The Name of Augustus," Journal of Roman Studies 5 (1915): 249-50.

90. Livy 1.19.1: “(Numa) urbem novam, conditam vi et armis, iure eam legibus ac moribus de integro condere parat."

91. Livy 1.19.2-4. The Greek translation of Janus in Res gestae 2.13 is "ПÍ $\lambda \eta \nu$ 'Evvvódiov." Janus was closed for the entire length of Numa's reign: Plut., Numa 20.2; Florus 1.2.3. Janus was the patron of civil and social order, who brought men out of a bestial state and into civilization: Plut., Numa 19.6. Virgil celebrated the first closing of Janus in the Aeneid following the victory at Actium: cf. Livy 1.19.3-4; Plut., Numa 19.1, 20. Florus 2.34.64 also describes the event: "As a result, everywhere in the inhabited world an unbroken peace or treaty of peace was firmly established, and Caesar Augustus dared at last, in the seven-hundredth year since the foundation of the city [29 B.C.E.] to close the twin doors of Janus, which had been closed before only two times, once under King Numa and next after the first defeat of Carthage [Sic ubique certa atque continua totius generis humani aut pax fuit aut pactio, aususque tandem Caesar Augustus septingentesimo ab urbe condita anno Ianum geminum claudere, bis ante se clusum sub Numa rege et victa primum Carthagine]." On Janus, see Wilhelm $\mathrm{H}$. Roscher, "Janus," in Ausführliches Lexikon der griechischen und römischen Mythologie (Leipzig: B. G. Teubner, 1890-94), vol. 2, pt. 1, 40; Robert Schilling, "Janus: Le dieu introducteur, le dieu des passages," Mélanges de l'École Française de Rome 72 (1960): 89-131; Holland (as in n. 62); Robert Turcan, "Janus à l'époque impériale," in $A N R W$, vol. 2 (1981), fasc. 17, sec. 1, 374-402; Magdelain (as in n. 64), 204: "As a god of passages, Janus oscillates between war and peace without ever becoming fixed on one or the other."

92. This was a most solemn augural rite to determine whether the consuls should ask the gods to protect the state's safety; it could be performed only at a time of peace: Suet., Aug. 31.4; Dio 37.24.

93. Augustus, Res gestae 2.13: "Janus Quirinus, which our ancestors wanted closed whenever peace through victory obtained throughout the entire Roman empire on land and sea, and which we are told was closed only twice since the foundation of the city before my birth, the Senate ordered closed three times during my principate [Ianum Quirinum, quem claussum esse maiores nostri voluerunt, cum per totum imperium populi Romani terra marique esset parta victoriis pax, cum prius, quam nascerer, a condita urbe bis omnino clausum fuisse prodatur memoriae, ter me principe senatus claudendum esse censuit]."

94. The pontifices supervised religious rites, observed prodigies, controlled the calendar, and directed the rites of burial: Livy 1.20.5-7; Plut., Numa 9.1-4, 11.1; Florus 1.2.2. The flamines: Dion. Hal. 2.64.1-2; Livy 1.20.1-3; Plut., Numa 7.4. The Salii: Dion. Hal. 2.70.1-5; Florus 1.2.2; Livy 1.20.4; Plut., Numa 
13.1-7. The name of Augustus is included in the Salian Hymn, and the Salii celebrated their rites in the Forum Augusti: Dion. Hal. 51.22.1; Res gestae 10. The camilli: Plut., Numa 7.5. Numa obedient to divine will: Dion. Hal. 2.64.4; Florus, 1.2.2. Both Numa and Romulus were credited with the creation of Vestal Virgins and the establishment of a temple in the Forum Romanum to the goddess: Dion. Hal. 2.64.5-2.65.1; Florus 1.2.3; Livy 1.20.3; Plut., Numa 9.5, 11.1. Flamen Quirinalis for Romulus: Dion. Hal. 2.63.3. Caesar's priest, the flamen Iulialis: Weinstock (as in n. 63), 305-8. Vesta: Livy 1.20.3. The goddess and her temple appear in a Palatine setting, for example, on the Sorrento base: Giulio E. Rizzo, "La base di Augusto," Bollettino della Commissione Archeologica Comunale di Roma 60 (1932): 7-109; Ryberg, 1955 (as in n. 6), 49-51; Nevio Degrassi, "La dimora di Augusto sul Palatino e la base di Sorrento," Atti della Pontificia Accademia romana di archeologia: Rendiconti 39 (1966-67): 77116; Simon, 1986 (as in n. 6), 24-25; Tonio Hölscher, "Historischer Reliefs," in Kaiser Augustus, 375-78; Aicher (as in n. 18); and Kleiner, 88, fig. 68. A procession of Vestal Virgins decorates the inner altar of the Ara Pacis.

95. Velleius Paterculus 2.59.4. See Gross (as in n. 42), 31. His earliest priesthood was given him by his adoptive father, Julius Caesar, before his assassination: Vell. Pat. 2.59.4. When Augustus introduced his grandsons and heirs into public life, their first priesthoods were the augurate and pontificate. The coins abbreviate augur as AVG, an abbreviation subsequently used for the title Augustus as well.

96. During the Republic even important individuals tended to hold just one priesthood. Res gestae 7 lists Augustus's priesthoods: pontifex maximus, augur, quindecimvir, septemvir epulonum, frater arvalis, sodalis Titius, and fetialis. Jean Gagé, "Les sacerdoces d'Auguste et ses réformes religieuses," Mélanges d'Archéologie et d'Histoire 48 (1931): 75-108; Galinsky, 313.

97. Glen Bowersock argues that Augustus actually appears as pontifex maximus on the Ara Pacis: "The Pontificate of Augustus," in Between Republic and Empire: Interpretations of Augustus and His Principate, ed. Kurt A. Raaflaub and Mark Toher (Berkeley: University of California Press, 1990), 380-94. John Carter favors this interpretation in his review of the book, Journal of Roman Studies 81 (1991): 201-2, but see Billows (as in n. 25), 84-87, for objections. At the time the altar was founded in 13 B.C.E., Augustus presumably cannot have known that he would become pontifex maximus a year later, since at the time Lepidus, his predecessor in office, was still alive, although in exile.

98. See Burkhard Gladigow, "Die sakralen Funktionen der Liktoren: Zum Problem von institutioneller Macht und sakraler Präsentation," in $A N R W$, vol. 1, fasc. 2 (1981), 295-314

99. Livy 1.19.6-7; Plut., Numa 18-19; Florus 1.2.3. Numa's twenty-year cycle is reminiscent of the Metonic cycle established in the 5 th century B.C.E., which was based on an ideal number of solar and lunar months. Holliday (as in n. 6) has argued that the Ara Pacis reflects philosophical concerns with a "Great Year." On Augustus's reform of Caesar's calendar, see Suet., Aug. 31.2. In 8 B.C.E. (if not earlier), the name of the month Sextilis was changed to August to honor the emperor because his greatest victories had been won in that month, including the conquest of Egypt: Suet., Aug. 1.2; Dio 55.6.6. The Ara Pacis was dedicated approximately twenty years after the conquest and triumph over Egypt.

100. Dion. Hal. 2.75.1-2; Plut., Numa 16.4.

101. Georg Niebling, "Laribus Augustis Magistri Primi," Historia 5 (1956): 303-31.

102. Numa built the temple of Quirinus on the Quirinal Hill, though the earliest edifice attested there dates to 293: Dion. Hal. 2.63.3. Augustus restored the temple of Quirinus (16 B.C.E.) and built a temple to divus Julius in the Forum Romanum. Numa built the Regia and lived there, although he also maintained a house on the Quirinal Hill, just as Augustus maintained his home on the Palatine even after he became pontifex maximus: Plut., Numa 14.1-2. In the Regia, Numa preserved the bucklers (ancilia) fallen from heaven for the preservation of the city, which were guarded by the Salii: Livy 1.20.4; Dion. Hal. 2.71.1-2; Plut., Numa 13.1-4; Florus 1.2.3.

103. Numa was identified as a philosopher-king and was often considered a pupil of Pythagoras, even though authors in antiquity recognized that they lived at different times: Livy 1.18.1-3; Plut., Numa 1.2-3, 8.4-10; Dion. Hal. 2.59.1-4. For context, see Elizabeth Rawson, Intellectual Life in the Late Roman Republic (Baltimore: Johns Hopkins University Press, 1985). A prominent Neopythagorean of the last century of the Republic, Publius Nigidius Figulus, forecast a wonderful future for Octavian when he was born (Suet., Aug. 94). Another Neopythagorean, Areius, was the companion of Octavian and influenced him heavily (Dio 51.16.4), and Pythagorean elements have been detected in Virgil's Aeneid and in the Metamorphoses of Ovid: Jerôme Carcopino, Virgile et le mystère de la IVe églogue (Paris: L'Artisan du Livre, 1943); and Pierre Boyancé, La religion de Virgile (Paris: Presses Universitaires de France, 1963).

104. Numa tamed the Romans and made them peaceful: Plut., Numa 7. Under his guidance, the Romans valued "good government, peace, agriculture, rearing of children, and worship of the gods" (Plut., Numa 19.3), which recalls the goals of Augustan social legislation. The subjects of Numa imitated his character spontaneously, and other nations thought it was sacrilegious to injure the Romans: Livy 1.21.2. In an interesting turn of phrase, Plutarch describes Numa's policies as a magical "peace potion [eirines philtron]" that encouraged agriculture and promoted peace: Plut., Numa 16.

105. L. Raditsa, "Augustus' Legislation concerning Marriage, Procreation, Love Affairs, and Adultery," in ANRW, vol. 2, fasc. 13 (1980), 278-339; Karl
Galinsky, "Augustus' Legislation on Morals and Marriage," Philologus 125 (1981): $126-44$.

106. Koeppel, 111-13, fig. 3. The specific identity of the central goddess on the relief has occasioned much debate, and many other identifications have been proposed for her, including Pax, Venus, Italia, Ceres, or a conflation of several divinities. See recently Nancy De Grummond, "Pax Augusta and the Horae on the Ara Pacis Augustae," American Journal of Archaeology 94 (1990): 663-67; Karl Galinsky, "Venus, Polysemy, and the Ara Pacis Augustae," American Journal of Archaeology 96 (1992): 457-75; Barbette S. Spaeth, "The Goddess Ceres in the Ara Pacis Augustae and the Carthage Relief," American Journal of Archaeology 98 (1994): 65-100; and idem, The Roman Goddess Ceres (Austin: University of Texas Press, 1996), 125-51. The relief figure lacks the cornucopia and caduceus that are the typical attributes of Pax, but this is surely because she is balancing the two babies. Contra Spaeth, the vegetation in her garland is not exclusive to Ceres.

107. Roma panel: Koeppel, 113-15, figs. 4-7.

108. Roma is based on an Amazon type with some additions from the iconography of Minerva/Athena, while Tellus belongs to a long line of mother goddesses in Greek and Italian art. As allegories, Peace and War form an obvious pair that any Roman audience could understand. On Roma, see Ronald Mellor, "The Goddess Roma," in ANRW, vol. 2 (1981), fasc. 17, sec. 2, 950-1030. A relief from the Zoilos Monument at Aphrodisias shows a seated Roma in this Amazonian aspect: Alföldi (as in n. 12), 14, pl. 26; Smith (as in n. 12). See also Ronald Mellor, Thea Rhome: The Worship of the Goddess Roma in the Greek World, Hypomnemata, 42 (Göttingen: Vandenhoek und Ruprecht, 1975).

109. Torelli (as in n. 1), 72, presents a somewhat similar interpretation, with the north side of the monument representing the pars militaris and the southern side the pars civilis. He claims (as in n. 2), 29, that the Ara Pacis was constructed one mile north of the pomerium, at the point where an imperator normally laid down his imperium; in fact, the altar is located substantially less than a mile away. In any case, Augustus was exempted from this requirement by the powers that had already been voted him.

110. Livia, however, wears a laurel wreath, while Tellus wears a wreath of fruit and flowers. See Elizabeth Bartman, Portraits of Livia: Imaging the Imperial Woman in Augustan Rome (Cambridge: Cambridge University Press, 1999), 86-92; Rolf Winkes, Livia, Octavia, Iulia: Porträts und Darstellungen, Archaeologia Transatlantica, vol. 13 (Louvain-la-Neuve: Université de Louvain-laNeuve; Providence, R.I.: Brown University, 1995). Cf. Marleen B. Flory, "The Symbolism of Laurel in Cameo Portraits of Livia," Memoirs of the American Academy in Rome 40 (1995): 43-68.

111. Pollini (as in n. 6), 78-80; Billows (as in n. 25), 88.

112. North frieze figures wearing senatorial shoes include N-6, N-18, N-20, $\mathrm{N}-21$. The camilli are $\mathrm{N}-7$ and $\mathrm{N}-24$.

113. Billows (as in n. 25); cf. the discussion by Gerhard Koeppel, "Die historischen Reliefs der römischen Kaiserzeit V, Ara Pacis," pt. 2, Bonner Jahrbucher 188 (1988): 97-106. Dio 54.25.3-4, however, records that on this occasion the princeps avoided all public ceremony and entered the city at night. If this is correct, then the reliefs are not truly "historical."

114. Cicero uses the toga as a metonym for peace, in De orat. 3.167: "sed ornandi causa proprium proprio commutatum ... 'togam' pro pace, 'arma' ac 'tela' pro bello." Virgil, Aen. 1.282, identifies the toga-wearing Romans as masters of the world ("Romanos, rerum dominos gentemque togatam"), a line that Augustus is said to have quoted when restricting entrance into the forum to those who wore the garment: Suet., Aug. 40.5. Drusus wears a military costume that includes boots, a short tunic, and military cloak (paludamentum). He appears to have remained in Germany in 13 B.C.E., when Augustus returned to Rome. For togate depictions of Roman children, see esp. Hans Gabelmann, "Römische Kinder in Toga Praetexta," Jahrbuch des Deutschen Archäologischen Instituts 100 (1985): 497-541.

115. Castriota (as in n. 6). See also Christoph Börker, "Neuattisches und Pergamenisches an der Ara Pacis-Ranken," Jahrbuch der Deutschen Archäologischen Instituts 88 (1973): 283-95; and Hermann H. Büsing, "Ranke und Figure an der Ara Pacis Augustae," Archäologischer Anzeiger, 1977: 247-57.

116. Koeppel, 146-51; these have not been incorporated in the current reconstruction of the monument. Cf. Paolo Liverani, "'Nationes' e 'civitates' nella propaganda imperiale," Römische Mitteilungen 102 (1995): 219-49; and Kuttner (as in n. 6), 69-93.

117. For example, Toynbee (as in n. 6), 77; Holliday (as in n. 6), 549, sees them as an allusion "to the origo urbis of Rome and the origo gentis of the Julian line." Galinsky, 1969 (as in n. 6), 219-26, and Kleiner, 96, espouse a similar view.

118. See above at n. 4 .

119. Holliday (as in n. 6), 549-550: "The discovery of an animal dominates the center [of each panel] and indicates the primal initia of uniquely Roman institutions: the she wolf of the urbs itself, and the sow of the gens Iulia." As noted earlier, the altar, not the animal, is the main focus of the relief.

120. Ibid., 550: "Mars pater and Aeneas pater officiate at a locus sacer analogous to the sacred precinct of the Ara Pacis-indicated by the fig tree (ficus Ruminalis) and the temple of the Penates." The temple in the background is far distant from the figures involved in the sacrifice, and as noted earlier, Augustus did not accept the title pater patriae until some years after the Ara Pacis was completed.

121. Galinsky (as in n. 106) has argued that the figure of "Tellus" is polysemantic, incorporating features of several goddesses. Galinsky, 1969 (as 
in n. 6), 219, 226, also identifies "Trojan" and "Roman" halves of the Ara Pacis. Spaeth, 1994 (as in n. 106), 83, argues that the "Aeneas" and Romulus panels reflect "the dual origin of Rome: her foreign origins from the Trojan Aeneas, and her native origins from the twins Romulus and Remus."

122. Paul Zanker, "In Search of the Roman Viewer," in The Interpretation of Architectural Sculpture in Greece and Rome, ed. Diana Buitron, Studies in the History of Art, vol. 49 (Hanover, N.H.: University Press of New England, 1 997), 179-91.

123. See, for example, the papers in Jás Elsner, ed., Art and Text in Roman Culture (Cambridge: Cambridge University Press, 1996)

124. Zanker, 205-6, notes that the scene on the panel is iconic rather than purely narrative. Richard Westall has recently analyzed two paintings dedicated in the temple of Venus Genetrix: "The Forum Julium as Representation of Imperator Caesar," Römische Mitteilungen 103 (1996): 83-118. Cf. Dietrich Boschung, "Nobilia opera: Zur Wirkungsgeschichte griechische Meisterwerke im kaiserzeitlichen Rom," Antike Kunst 32 (1989): 8-16; Bettina Bergmann, "Greek Masterpieces and Roman Recreative Fictions," Harvard Studies in Classical Philology 97 (1995): 79-120; Renaud Robert, "Immensa Potentia Artis: Prestige et statut des oeuvres d'art à Rome à la fin de la république et au début de l'Empire," Revue Archéologique, 1995: 291-305; and Peter J. Holliday, "Roman Triumphal Painting: Its Function, Development, and Reception," Art Bulletin 79 (1997): 130-47. A non-Greek source for the composition on the Ara Pacis relief may be sought as well in Etruscan mold-made votive terra-cotta plaques. A 4th century B.C.E. plaque in Boston, for example, is framed by architectural elements and shows a central altar, and behind it a tree. To the left of the altar is a small female flute player with her pipes, while Artemis stands to the right in three-quarter view, extending her right hand with patera over the altar. Behind her we see a quadruped that represents the intended victim: Helen Nagy, "Divinities in the Context of Sacrifice and Cult on Caeretan Votive Terracottas," in Murlo and the Etruscans: Art and Society in Ancient Etruria, ed. Richard De Puma and J. Penny Small (Madison: University of Wisconsin Press, 1992), 211-23, esp. 211-13, fig. 19.1.

125. Virgil, Aen. 1.453-93. See recently Michael Putnam, "Dido's Murals and Virgilian Ekphrasis," Harvard Studies in Classical Philology 98 (1998): 243-75 (with earlier bibliography); and Gerhard Koeppel, "The Role of Pictorial Models in the Creation of the Historical Relief during the Age of Augustus," in Winkes (as in n. 4), 89-106.

126. In the Ara Pacis panels, the landscape and even the animals are subordinated to the human figures. Compare the Odyssey panels from the Esquiline House, where the human figures, labeled in Greek, are subordinated to the landscape. Of the extensive bibliography on these paintings, see recently Ralf Biering, Die Odysseefresken von Esquilin, Studien zur antiken Malerei und Farbgebung, vol. 2 (Munich: Biering und Brinkmann, 1995) Kaiser Augustus, 282-83, nos. 131, 132 (with bibliography), ills., 284-85; and Filippo Coarelli, "The Odyssey Frescoes of the Via Graziosa: A Proposed Context," Papers of the British School in Rome 66 (1998): 21-37. Biering argues that the paintings are Augustan in date; Coarelli favors the traditional late Republican date of ca. $50-40$ B.C.E.

127. Augustus, Res gestae 34: "After that time [27 B.C.E.] I was preeminent in respect to rank, but I had no more actual power than those who were colleagues with me in any magistracy [post id tempus praestiti omnibus dignitate, potestatis autem nihilo amplius habui quam qui fuerunt mihi quoque in magistratu conlegae]." During recent decades, there has been a steady move away from the position taken by Ronald Syme in The Roman Revolution (Oxford: Clarendon Press, 1939), for example, by Galinsky. See, however, Dietmar Kienast, Augustus: Prinzeps und Monarch (Darmstadt: Wissenschaftliche Buchgesellschaft, 1982; reprint, 1999); Michael Mause, "Augustus: 'Friedensfürst' in einer unruhigen Zeit," Klio 81 (1999): 142-55.

128. Janus was the god of time as well as of the beginning of the year. Pliny, $N H 34.16 .34$, mentions a statue of Janus erected by Numa that had its fingers arranged in such a manner as to indicate the 355 days of the early Roman year and to show that Janus was the god of time: "praeterea Ianus geminus a Numa rege dicatis, qui pacis bellique argumento colitur digitis ita figuratis, ut ccclv dierum nota et aevi esse deum indicent."

129. Ancient sources give conflicting boundaries for the Campus Martius, but Strabo includes the mausoleum of Augustus, which lies even farther north than the Ara Pacis and Horologium-Solarium. Suet., Aug. 100, reports that Augustus opened the gardens surrounding the mausoleum to the public in 28 B.C.E., which suggests (but does not prove) that the construction of the tomb was well advanced by this date.

130. On the tomb itself, see Henner von Hesberg and Silvia Panciera, Das Mausoleum des Augustus: Der Bau und seine Inschriften (Munich: Verlag der Bayerischen Akademie der Wissenschaften, 1994); Konrad Kraft, "Der Sinn des Mausoleum der Augustus," Historia 16 (1967): 186-202; Zanker, 72-77; Mark J. Johnson, "The Mausoleum of Augustus: Etruscan and Other Influences on Its Design," in Etruscan Italy: Etruscan Influences on the Civilizations of Italy from Antiquity to the Modern Era, ed. John F. Hall (Provo, Utah: Museum of Art, Brigham Young University, 1996), 217-39; and Penelope J.E. Davies, Death and the Emperor: Roman Imperial Funerary Monuments from Augustus to Marcus Aurelius (Cambridge: Cambridge University Press, 2000), 13-15, 13742. The obelisks have been considered a Flavian addition, but on the basis of recent excavations at the mausoleum, Edmund Buchner assigns them an Augustan date: "Ein Kanal für Obelisken: Neues vom Mausoleum des Augustus in Rom," Antike Welt 27 (1996): 161-68. For two very different interpre- tations of the publication of the Res gestae at the mausoleum, see Jás Elsner, "Inventing Imperium: Texts and the Propaganda of Monuments in Augustan Rome," in Elsner (as in n. 123), 32-53; and Brian Bosworth, "Augustus, the Res Gestae and Hellenistic Theories of Apotheosis," Journal of Roman Studies 89 (1999): 1-18. On the importance of such inscriptions, see Callie Williamson, "Monuments of Bronze: Roman Legal Documents on Bronze Tablets," Clas sical Antiquity 6 (1987): 160-83; and Geza Alföldi, "August und die Inschriften: Tradition und Innovation; Die Geburt der imperialen Epigraphik," Gymnasium 98 (1991): 289-324.

131. Edmund Buchner, "Solarium Augusti und Ara Pacis," Römische Mitteilungen 83 (1976): 319-63; idem, "Horologium Solarium Augusti: Vorbericht über die Ausgrabungen 1979/80," Römische Mitteilungen 87 (1981): 355-73; idem, Die Sonnenuhr des Augustus: Nachdruck aus RM 1976 und 1980 und Nachtrag über die Ausgrabung 1980/1981 (Mainz: Philipp von Zabern, 1982); idem, "Horologium Solarium Augusti," in Kaiser Augustus, 240-44; and idem, "Horologium Augusti," in LTUR, vol. 3 (1996), 35-37. Cf. comments by Andrew Wallace-Hadrill, "Rome's Cultural Revolution," Journal of Roman Studies 79 (1989): 157-64.

132. Senators were forbidden to go there without the express permission of the princeps.

133. Pliny, $N H$ 36.14.71; Richardson (as in n. 1), s.v. "obeliscus Augusti," 272-73; Corpus Inscriptionum Latinarum (CIL), vol. 6, 702. The obelisk was quarried by Psammeticus II (r. 594-589 B.C.E.), not Ramses II, as Pliny states. The dedicatory inscription and the way the obelisk functioned have been seriously misunderstood in two recent studies by Diane Favro: "Reading the Augustan City," in Holliday, 230-57; idem, The Urban Image of Augustan Rome (Cambridge: Cambridge University Press, 1996), 130, 148. Inter alia, the inscription does not mention Cleopatra, and at Rome's latitude, the obelisk cast a shadow only northward. Davies (as in n. 130) incorrectly states that the shadow described a circle around the obelisk, another impossibility.

134. Often cited in this connection is Virgil, Eclogue 4.4-10: "Now the final age of the Cumaean song is come; the grand order of the centuries is born again. Now the Virgin [Justice] has returned, along with the reign of Saturn. Now a new race descends from high heaven. Look kindly, Lucina, on the birth of this child, with which the iron race of men will cease, and a new golden one will rise up throughout the world. Your own Apollo now reigns! [ultima Cumaei venit iam carminis aetas; / magnus ab integro saeculorum nascitur ordo. / iam redit et Virgo, redeunt Saturnia regna; / iam nova progenies caelo demittitur alto. / tu modo nascenti puero, quo ferrea primum / desinet ac toto surget gens aurea mundo, / casta fave Lucina: tuus iam regnat Apollo]."

In a neglected article, D. A. Slater suggested convincingly that the poem was written not for Augustus but for the marriage of Antony and Octavia (Augustus's sister) in 40 B.C.E.: "Was the Fourth Eclogue Written to Celebrate the Marriage of Octavia to Mark Antony?" Classical Quarterly 26 (1912): 114-19. Augustus simply attempted to situate himself within a tradition that was already widespread. Sol plays a prominent role in Horace: Karl Galinsky, "Sol and the Carmen Saeculare," Latomus 26 (1967): 619-33.

135. For example, Suet., Aug. 94.4; Dio 45.1.2. See Eugenio La Rocca, "Theoi epiphaneis: Linguaggio figurativo e culto dinastico da Antiochos IV ad Augusto," in Macht und Kultur in Rom der Kaiserzeit, ed. Klaus Rosen (Bonn: Bouvier, 1994), 9-63; Pierre Lambrechts, Augustus en de Egyptische Godsdienst (Brussels: Paleis der Academien, 1956); Ilse Becher, "Oktavians Kampf gegen Antonius und seine Stellung zu den ägyptischen Göttern," Das Altertum 11 (1965): 40-47.

136. Weinstock, esp. 44-50; Erich Gruen, "Augustus and the Ideology of War and Peace," in Winkes (as in n. 4), 51-72. Livy 1.19.2 specifically connects the closing of Janus with the pacification of Rome's neighbors. In this context, recall the personifications on the base of the inner altar, which may represent provinces, above at $n$. 116. Augustus makes the connection between peace and victory explicit in Res gestae 2.13 where he talks about his closing of Janus.

137. Dio 51.19.2-3. See also discussion in Weinstock (as in n. 63), 209-10. Objections have been raised to some aspects of Buchner's calculations for reconstructing the Horologium, for example, by Michael Schütz, "Zur Sonnenuhr des Augustus auf dem Marsfeld," Gymnasium 97 (1990): 432-57; and Walter F. Hübner, review of Buchner, 1982 (as in n. 131), Trier Zeitschrift 46 (1983): 333-38. But cf. the response by Buchner in LTUR, vol. 3 (as in n. 131), and by Roger Beck in Apeiron: The Sciences in Greco-Roman Society, ed. Timothy D. Barnes, 27 (1994): 99-117, esp. 104-5. The basic correctness of Buchner's case for a programmatic relation between the sundial and the Ara Pacis seems secure, for we can extend the north-south meridian line (uncovered by excavation) and bisect it in the middle to compute the east-west line that the shadow of the gnomon traced on the equinoxes; this line intersects the doorway in the west facade of the Ara Pacis, the original position of which is also known through excavation. As Beck points out, while Schütz demonstrated that the shadow cast by the obelisk would not actually reach the Ara Pacis, spectators nevertheless would have seen the shadow pointing toward the monument and would have understood the general message.

138. The astrologer Publius Nigidius Figulus (who also predicted Augustus's world rule) calculated that Romulus, like Augustus, was born on the autumnal equinox. Pierre Brind'Amour has challenged this date, and argues that the actual birth date of Romulus was the vernal equinox: Le calendrier romain: Recherches chronologiques (Ottawa: Éditions de l'Université d'Ottawa, 1983), 240-49. Whichever date is "correct" (for this is all playing with numbers), the shadow of the gnomon would have fallen toward the Ara Pacis 
on both equinoxes. See Tamsyn Barton, Ancient Astronomy (London: Routledge, 1994); idem, Power and Knowledge: Astronomy, Physiognomics and Medicine under the Roman Empire (Ann Arbor: University of Michigan Press, 1994); idem, "Augustus and Capricorn: Astrological Polyvalency and Imperial Rhetoric," Journal of Roman Studies 85 (1995): 33-51; and Scott (as in n. 70), 82-105.

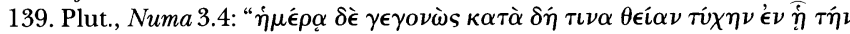
'P

140. CIL 1.315: "Romulus urbem inauguravit." On the importance of calendars and the control of time, see Andrew Wallace-Hadrill, "Time for Augustus: Ovid, Augustus and the Fasti," in Homo Viator: Classical Essays for John Bramble, ed. Michael Whitby, Philip Hardie, and Mary Whitby (Bristol: Bristo Classical Press, 1987), 221-30; idem, "Mutatio morum: The Idea of a Cultura Revolution," in The Roman Cultural Revolution, ed. Thomas Habinek and Alessandro Schiesaro (Cambridge: Cambridge University Press, 1997), 3-22, esp. 16-18; and Mary Beard, "A Complex of Times: No More Sheep on Romulus' Birthday," Proceedings of the Cambridge Philosophical Society 213 (1987): $1-15$.

141. Livia's birthday: Fasti Praenestini for January 30. Anthony A. Barrett "The Year of Livia's Birth," Classical Quarterly 49 (1999): 630-32, argues that she was born in 59 B.C.E., not 58, as is usually assumed. The Fasti Praenestini record a series of important dates connected with the imperial family. Augustus mentions in the Res gestae that this dedication date was marked by an annual sacrifice (see n. 48 above). The Feriale Cumanum records the supplicatio: "[eo die Ara Pacis Aug. dedicata] est. supplicatio imperio Caesaris Augusti cost[odis civium Romanorum orbisque terrar]um."

142. Dio (as in n. 137). Werner Suerbaum, "Merkwürdige Geburtstage: Der nicht-existerende Geburtstag des M. Antonius, der doppelte Geburtstag des Augustus, der neue Geburtstag der Livia und der vorzeitige Geburtstag des älteren Drusus," Chiron 10 (1980): 327-55.

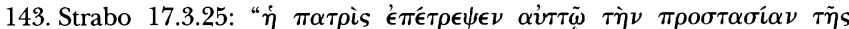

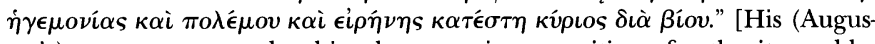
tus's) country entrusted to him the preeminent position of authority, and he became established as the lord (kurios) for life of war and peace].

144. Cf. Marta Sordi, "L'idea di crisi e di rinnovamento nella concezione romano-etrusca della storia," in ANRW, vol. 1, fasc. 2, 781-93. See also Holliday (as in n. 6).

145. "Ita duo deinceps reges, alius alia via, ille bello, hic pace, civitatem auxerunt ... cum valida tum temperata et belli et pacis artibus erat civitas." Note Livy's use of auxerunt, from augeo, the verb connected with the title "Augustus." 